\title{
Evaluating Infectious, Neoplastic, Immunological, and Degenerative Diseases of the Central Nervous System with Cerebrospinal Fluid-Based Next-Generation Sequencing
}

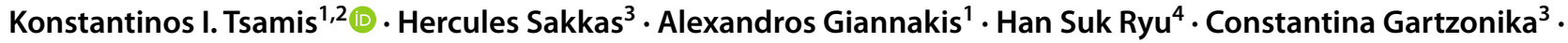 \\ Ilias P. Nikas ${ }^{2}$
}

Accepted: 7 January 2021 / Published online: 1 March 2021

(c) The Author(s), under exclusive licence to Springer Nature Switzerland AG part of Springer Nature 2021

\begin{abstract}
Cerebrospinal fluid (CSF) is a clear and paucicellular fluid that circulates within the ventricular system and the subarachnoid space of the central nervous system (CNS), and diverse CNS disorders can impact its composition, volume, and flow. As conventional CSF testing suffers from suboptimal sensitivity, this review aimed to evaluate the role of next-generation sequencing (NGS) in the work-up of infectious, neoplastic, neuroimmunological, and neurodegenerative CNS diseases. Metagenomic NGS showed improved sensitivity - compared to traditional methods - to detect bacterial, viral, parasitic, and fungal infections, while the overall performance was maximized in some studies when all diagnostic modalities were used. In patients with primary CNS cancer, NGS findings in the CSF were largely concordant with the molecular signatures derived from tissue-based molecular analysis; of interest, additional mutations were identified in the CSF in some glioma studies, reflecting intratumoral heterogeneity. In patients with metastasis to the CNS, NGS facilitated diagnosis, prognosis, therapeutic management, and monitoring, exhibiting higher sensitivity than neuroimaging, cytology, and plasma-based molecular analysis. Although evidence is still rudimentary, NGS could enhance the diagnosis and pathogenetic understanding of multiple sclerosis in addition to Alzheimer and Parkinson disease. To conclude, NGS has shown potential to aid the research, facilitate the diagnostic approach, and improve the management outcomes of all the aforementioned CNS diseases. However, to establish its role in clinical practice, the clinical validity and utility of each NGS protocol should be determined. Lastly, as most evidence has been derived from small and retrospective studies, results from randomized control trials could be of significant value.
\end{abstract}

\section{Introduction}

Cerebrospinal fluid (CSF) is a clear and paucicellular fluid of low protein concentration, derived from the blood plasma and produced by the ependymal cells of the choroid plexus. In normal conditions, ependymal cells can produce around

Konstantinos I. Tsamis

ktsamis@uoi.gr

1 Department of Neurology, University Hospital of Ioannina, 45500 Ioannina, Greece

2 School of Medicine, European University Cyprus, 2404 Nicosia, Cyprus

3 Microbiology Department, Faculty of Medicine, School of Health Sciences, University of Ioannina, 45110 Ioannina, Greece

4 Department of Pathology, Seoul National University Hospital, Seoul 03080, Korea

\section{Key Points}

Compared to traditional microbiological methods, CSF-based metagenomic NGS has exhibited improved sensitivity to detect bacterial, viral, fungal, and parasitic CNS infections presenting as meningitis, encephalitis, or myelitis.

In patients with primary or metastatic CNS tumors, CSFbased NGS could facilitate diagnosis and classification, prognosis, treatment selection, and follow-up, besides highlighting cancer heterogeneity and pinpointing mechanisms of therapy resistance.

CSF-based NGS has helped decipher pathogenetic mechanisms and identify potential biomarkers (e.g., miRNAs) of multiple sclerosis, Alzheimer disease, Parkinson disease, and amyotrophic lateral sclerosis, but evidence is still rudimentary. 
$500 \mathrm{~mL} /$ day of CSF, of which $150 \mathrm{~mL}$ circulates within the ventricular system and the subarachnoid space of the central nervous system (CNS) [1, 2]. Being a crucial component of the CNS structure, any change in the cellular/biochemical composition, volume, and flow of the CSF could affect CNS function, and CNS disorders may alter CSF characteristics [2]. These changes are caused by various diseases that impact the CNS either primarily or secondarily, while CSF examination often helps to identify the cause $[1,2]$.

Physicians sample CSF by performing a procedure called a lumbar puncture, where they insert a needle within the L3-L4 or L4-L5 intervertebral space of the patient, and subsequently send the samples to the laboratory for analysis [3]. Currently, the main diagnostic indications of CSF testing include confirming or excluding CNS infections that cause meningitis or meningoencephalitis, CNS primary or metastatic neoplasms, subarachnoid hemorrhage, and neuroinflammatory disorders such as multiple sclerosis (MS) [2, 3]. For instance, identifying numerous neutrophils in the CSF supports a bacterial infection, whereas malignant cells confirm the presence of a cancer disseminating within the subarachnoid space $[1,2]$.

Although vital for everyday clinical practice, conventional CSF testing has significant drawbacks, the most important of them being suboptimal sensitivity. Morphologic evaluation of infectious agents (e.g., using Gram stain), cultures, or serologic testing often leave patients undiagnosed, while polymerase chain reaction (PCR) testing needs a formal hypothesis for the potential infectious agents implicated to select the most suitable primers. As a result, antimicrobial treatment could cause delay or even be inappropriate, with significant impact on morbidity and mortality $[4,5]$. Likewise, CSF cytology shows sensitivity of $<50 \%$ to detect cancer dissemination into the subarachnoid space, even if it is highly specific $[6,7]$. While the presence of oligoclonal bands-which represent increased concentrations of IgG immunoglobulins-in the CSF characterizes most MS cases, these bands could also be detected in other inflammatory or even neoplastic CNS conditions [8]. Of interest, CSF examination could provide answers where other diagnostic modalities fail or may harm the patients; for instance, when a brain biopsy fails to diagnose and assess the molecular profile of a CNS tumor or it is contraindicated due to the tumor location or the condition of the patient's health, CSF testing is a viable option [9].

In contrast to Sanger sequencing, next-generation sequencing (NGS) can process multiple nucleic acid fragments in parallel and within a single run, at both genomic (DNA) and transcriptomic levels (coding or noncoding RNA) [10]. Selection from various existing NGS-based methods depends on the clinical scenario. Targeted NGS using predefined panels is commonly applied in oncology [11], while metagenomic NGS (mNGS) is an emerging application in microbiology laboratories; mNGS is able to identify all pathogens present in a sample and in an unbiased way, without depending on a hypothesis, such as with PCR [12]. MicroRNA (miRNA) NGS can identify short, singlestranded, non-coding RNAs that regulate gene expression at the post-transcriptional level, and have acted as diagnostic and prognostic biomarkers in various disorders [13-15]. This review aims to highlight the value of applying NGS in the CSF of patients with infectious, neoplastic, neuroimmune, and neurodegenerative CNS diseases.

\section{CNS Infections}

Infections of the CNS-associated with bacteria, viruses, parasites, fungi, and prions - are a major cause of morbidity and mortality, especially in immunocompromised individuals $[16,17]$. Based on the predominant anatomic site of infection, CNS diseases are usually classified as meningitis, encephalitis (or meningoencephalitis), or myelitis (or encephalomyelitis). Acute meningitis may be caused by bacteria or viruses, while fungi, mycobacteria, or atypical bacteria are usually involved in chronic meningitis [17]. The rapid identification of the pathogen is essential for the process of antimicrobial therapy and its impact on clinical outcomes [18]. More than 100 pathogens, commonly viruses, have been reported as causative agents of encephalitis; however, most of the cases remain undiagnosed or even underestimated and the selection of an appropriate diagnostic method must be the ultimate objective $[19,20]$.

It has been reported that in approximately $75-80 \%$ of pediatric CNS infections, microbiological diagnosis is usually obtained with molecular laboratory methods [21]. Recently, mNGS technology of the CSF has been suggested as a fast, sensitive, affordable but also costly and laborintensive diagnostic tool, detecting unidentified pathogens in a single run, since culture, serologic procedures, and PCR have occasionally been proven ineffective $[5,16,21-26]$. This technology allows rapid sequencing of full pathogen genomes, even in point-of-care diagnostics, overcoming the limitations of available targeted PCR methods. It is useful in the examination of a large number of cases or small outbreaks, through accurate genotyping and molecular epidemiology, and also by characterization of genes mediating drug resistance [22, 27-29]. Interestingly, in a recent study, NGS of ancient dental calculus samples from a prehistoric site revealed high levels of Neisseria meningitidis and low levels of Haemophilus influenzae, which was interpreted as an ancient case of meningococcal disease associated with incipient endocranial lesions and pronounced meningeal grooves [30]. Nevertheless, clinical application is still in an early phase and there are several limitations [31] as most of the published reports consist of single case reports or small 
retrospective case series [32]. In addition, direct comparison between conventional testing and mNGS should rely on the definition of the gold standard method, further adding to the difficulty in validating such a new technology [31]. It has been shown that several background and contaminating bacteria (e.g., Propionibacterium, Burkholderia, Acinetobacter species) [33] and DNA contamination from CSF pleocytosis, a common feature in meningitis patients, considerably reduce the sensitivity of mNGS in the detection of pathogens [34]. Furthermore, several challenges including the improvement of bioinformatics software tailored for clinical diagnostic use and concerns over the quality and comprehensiveness of available reference databases still exist in making mNGS more applicable into laboratory practice [16]. Laboratory diagnosis of CNS infections with mNGS and the characteristics of the studies are summarized in Table 1 and Fig. 1.

\subsection{Bacteria}

Streptococcus pneumoniae followed by Streptococcus agalactiae, $N$. meningitidis, H. influenzae, and Listeria monocytogenes have been reported as the most common causes of acute bacterial meningitis [35]. Rapid diagnosis and treatment reduce mortality and neurological consequences, but this can be delayed by atypical clinical presentation, evaluation of the lumbar puncture safety, and poor sensitivity of conventional diagnostic methods [36]. Common pathogens including N. meningitidis, Streptococcus spp., L. monocytogenes, Escherichia coli, Pseudomonas aeruginosa, and Klebsiella pneumoniae [26, 28, 37], but also rare opportunistic pathogens such as Psychrobacter spp. [38] have been successfully detected in CSF specimens of pediatric and adult patients. Zhang et al. analyzed the diagnostic value of mNGS for identifying $S$. pneumoniae in pediatric bacterial meningitis. Results obtained by mNGS were compared to those from CSF culture, which is recognized as the "gold standard" method [39], although culture-based methods are less sensitive than molecular techniques, because most patients usually receive antibiotics prior to admission [40]. The sensitivity and specificity of mNGS for detecting $S$. pneumoniae were $73.1 \%$ and $88.1 \%$, respectively, whereas the positive predictive value (PPV) and negative predictive value (NPV) were $81.4 \%$ and $89.3 \%$, respectively. In addition, the difference in number of unique reads of bacteria from CSF samples collected up to 14 days from disease onset was significantly higher than the pathogen load from the sample collected over 14 days from the clinical onset [39]. In another study, NGS was applied for the investigation of two N. meningitidis serogroup C isolates from a meningococcal outbreak, classified within the same $N$. meningitidis sequence type ST-11 by conventional molecular techniques. Results demonstrated subtle genetic differences among the above mentioned isolates [28], providing useful information about the epidemic potential and dynamics of geographic distribution of distinct meningococcal serotypes [41].

L. monocytogenes is also an important bacterial cause of meningoencephalitis in immunocompromised individuals, with a high mortality rate. The positivity rates of Gram stain and CSF culture have been reported to be $14 \%$ and $41 \%$, respectively, and NGS recently identified and sequenced L. monocytogenes from three cases of clinically suspected meningoencephalitis [26]. In another study, four patients with a clinically suspected CNS infection and non-specific clinical manifestations were diagnosed with neurobrucellosis using NGS of the CSF, while only one patient (25\%) had a positive CSF culture. Furthermore, it is estimated that approximately $28 \%$ and $15 \%$ of patients with CNS brucellosis have positive blood cultures and CSF cultures, respectively, and although serological procedures are both more sensitive and faster than conventional culture, seropositivity is high in endemic areas and may not easily distinguish active from past infections [33, 42].

Infections with Mycobacterium tuberculosis (MTB) may occur with CNS comorbidities in approximately $1 \%$ of cases and are associated with significant mortality and adverse neurologic outcomes [17]. In a retrospective analysis, 51 inpatients with suspected tuberculous meningitis were examined with mNGS and four other assays in CSF. The sensitivity, specificity, PPV, and NPV of mNGS were $84.4 \%$, $100 \%, 100 \%$, and $46.1 \%$, respectively, while sensitivity was significantly higher than that of acid-fast staining ( $0 \%)$, CSF culture (22.2\%), MTB RT-PCR (24.4\%), and Xpert MTB/ RIF (40\%) [43]. In another study, the sensitivity of mNGS, acid-fast staining, CSF culture, and MTB RT-PCR in the first CSF samples from patients with definite tuberculous meningitis were $66.7 \%, 33.3 \%, 8.3 \%$, and $25 \%$, respectively, whereas the specificity of all procedures was $100 \%$ [44]. Lately, mNGS has also been evaluated for Ureaplasma parvum detection in the CSF of a neonate with meningitis [45].

\subsection{Viruses}

In more than half of cases, the etiological cause of CNS viral diseases remains unknown. Non-specific culture assays, serological tests (e.g., ELISA) and molecular techniques with high sensitivity and specificity (e.g., quantitative PCR) have been used as diagnostic tools, but they are compromised by several limitations since they are targeted against individual viruses or subsets of similar viruses [24]. NGS seems to be a promising method for the diagnosis of both DNA and RNA viral infections as it enables the detection and identification of known as well as novel pathogens [46, 47]. Although viruses in terms of genome size may be small, and their viral load may be undetectable due to the high concentration of background nucleic acids, viral metagenomics 


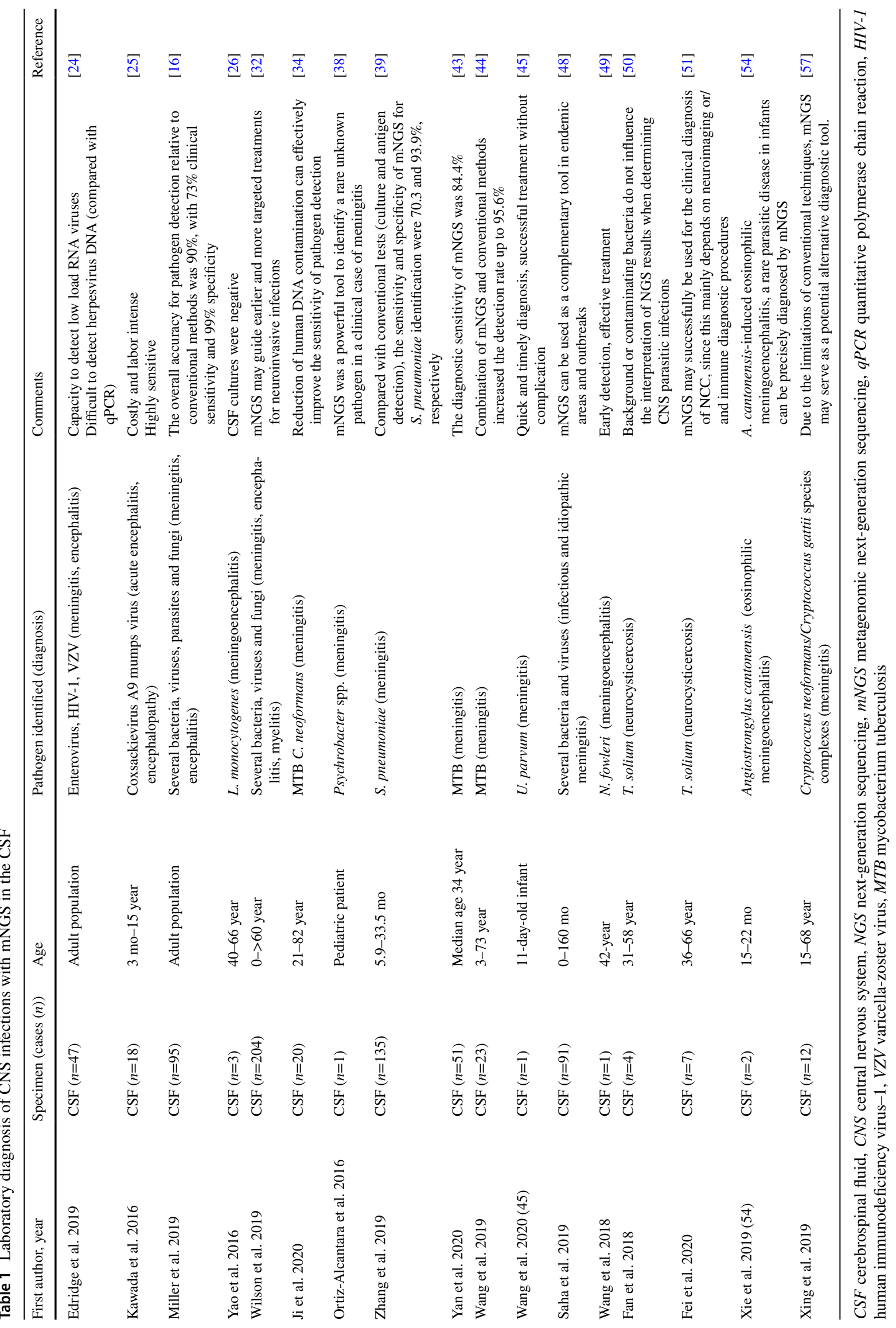




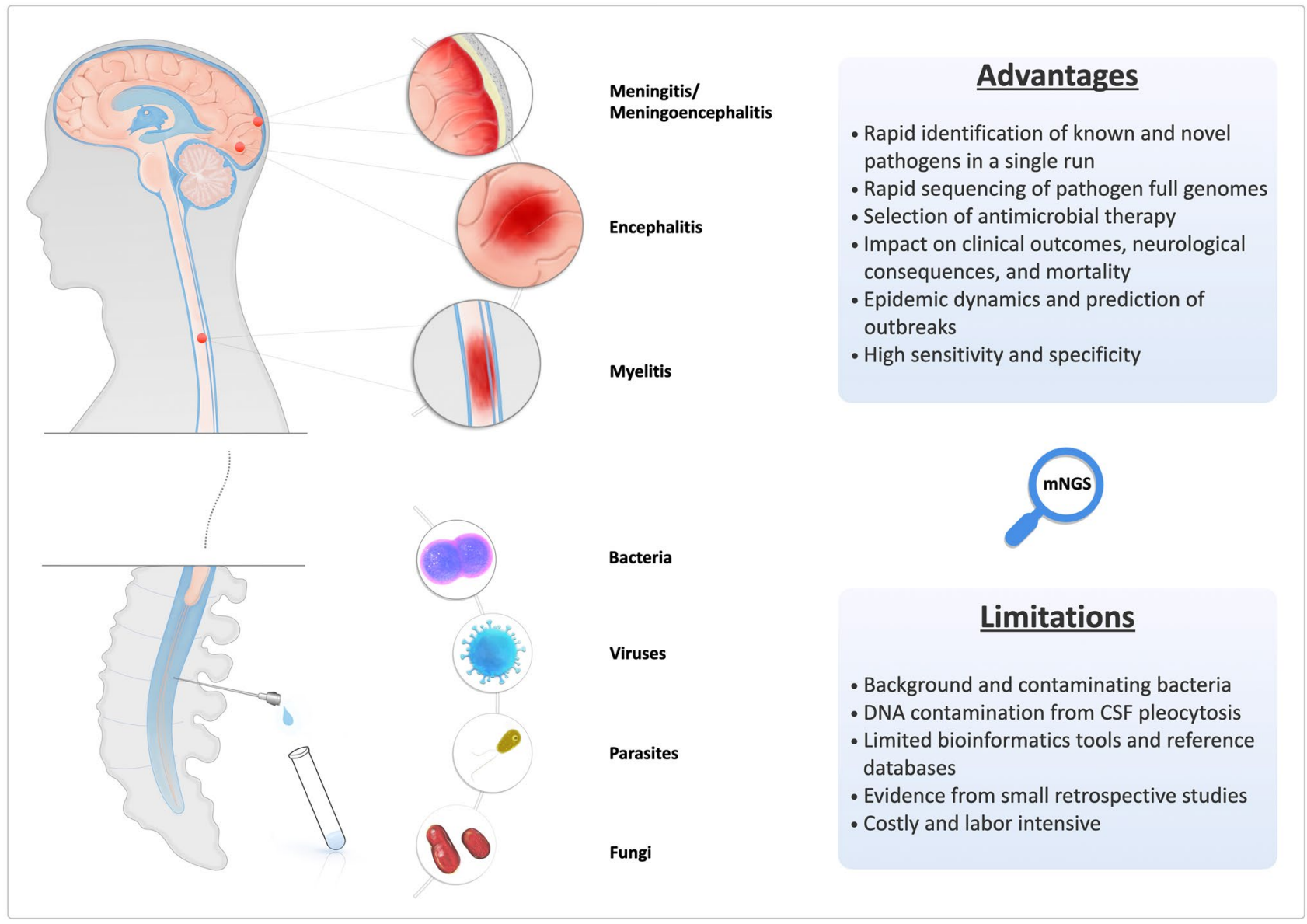

Fig. 1 The role of CSF-based metagenomic next-generation sequencing (mNGS) in the diagnosis of CNS infections: advantages and limitations. $C S F$ cerebrospinal fluid, CNS central nervous system

overcomes this by the enrichment of the viral genomic content in the sample [24].

Herpes viruses, measles virus, Coxsackieviruses, and Polyomaviruses have been identified by mNGS from CSF, pooled nucleic acids from CNS specimens and brain biopsies as known causes of encephalitis. Arenaviruses, Astroviruses, Bornaviruses, Coronaviruses, and Parvoviruses are considered novel causes of encephalitis. Cycloviruses, Densoviruses, and Gemycircularviruses have been isolated as unexpected pathogens from clinical specimens, demonstrating an unclear association with the reported infections [22]. Especially in low- and middle-income countries, unbiased mNGS can complement conventional diagnostic methods in order to identify potentially pathogenic viruses that cause epidemics, such as Chikungunya virus and as well as other RNA viruses, but also may be useful for the conduction of surveillance studies, and prediction of outbreaks [48]. Although techniques to reduce host DNA contamination from CSF samples are still lacking, several effective approaches have been used in order to improve the detection sensitivity of pathogens [34]. Using negative controls with predetermined DNA composition has been shown to be a necessary option to define the expected microbial nucleic acid background [29]. Nevertheless, mNGS should be performed in combination with conventional methods in order to diagnose a viral infection in patients presenting with mildto-moderate lymphocytic pleocytosis [32].

\subsection{Parasites}

In contrast to bacterial and viral infections, laboratory diagnosis of some parasitic infections cannot be primarily accomplished by conventional methods. Parasites are more frequently found in immunocompromised than immunocompetent patients with meningoencephalitis, while the most common CNS protozoan infection in the former is Toxoplasma gondii [17]. In a recent study, toxoplasmic encephalitis with atypical brain imaging features and negative results of Toxoplasma IgM antibodies test, was rapidly diagnosed by an mNGS method, in a critically ill 
HIV-infected individual [19]. In addition, NGS technology was successfully used in the accurate diagnosis of primary amoebic meningoencephalitis, an acute and life-threatening disease caused by Naegleria fowleri [49].

Regarding helminths, neurocysticercosis caused by Taenia solium is the most common infection of the CNS. The clinical manifestations and MRI findings may vary due to several factors, such as the number, stage, size, and different locations of the encysted larvae, thus the diagnosis usually becomes quite challenging. Also, considering the variable PPV of the available serological experiments, detection of T. solium DNA in CSF with NGS could facilitate diagnosis $[50,51]$. In such a case, a patient who presented for several months with atypical clinical symptoms including headache and paroxysmal left face and arm numbness, was diagnosed with neurocysticercosis using NGS in the CSF [52]. Furthermore, when compared with CNS bacterial infections, the NGS results for neurocysticercosis are readily interpreted, since they are not influenced by the existing background or contaminating bacteria [50]. Angiostrongylus cantonensis is the most common parasitic nematode cause of eosinophilic meningitis. Since the diagnosis of angiostrongyliasis also lacks standardized and confirmatory assays including serological tests and CSF cytology, the development of a precise diagnostic method is a challenge. A recent report has described a case of angiostrongyliasis confirmed by NGS in the CSF of a patient with ELISA-negative results [53]. Similarly, NGS was considered to have higher sensitivity and specificity when compared to microscopy, serological tests, and MRI in the detection of A. cantonensis eosinophilic meningoencephalitis in two infants [54].

\subsection{Fungi}

Fungal CNS infections with either yeasts or molds can cause severe neurological manifestations of either meningitis or focal abscess and cause life-threatening complications in the immunocompromised host. Most of these pathogens are acquired through the respiratory tract and secondarily disseminate though the hematogenous route to the CNS [17]. Among fungal infections, the opportunistic infection with Cryptococcus neoformans/Cryptococcus gattii species complexes has become the leading cause of meningitis among $\mathrm{HIV}$-infected patients and is associated with high morbidity and mortality rates $[55,56]$. mNGS has been successfully applied as an important diagnostic tool for rapid and specific diagnosis of cryptococcal infection in CSF samples, especially for accurate species identification, in conjunction with the traditional diagnostic methods including India ink staining, CSF culture, and cryptococcal antigen detection [57]. Recently, mNGS has been reported as a more sensitive procedure than conventional CSF culture and cryptococcal antigen test for the detection of Cryptococcus spp. at even low abundance in CSF of HIV-infected individuals. In this study, three HIV-seropositive, cryptococcal antigenemic patients with clinical features of meningitis and negative CSF microbiological procedures were finally diagnosed with cryptococcal meningitis by mNGS [58]. Diverse fungal pathogens including members of the genera Aspergillus, Histoplasma, and Candida have been also successfully identified by NGS technology [59].

\section{CNS Cancers}

As most primary and metastatic tumors involving the CNS show poor prognosis, their prompt diagnosis along with effective personalized therapy and close follow-up are imperative [60-62]. To this end, tumor molecular profiling is increasingly used in the clinic as an integral part of precision oncology [63, 64]. Molecular tumor data are often collected with tissue-based testing, either small biopsy or resection specimens [62]. However, invasive CNS procedures could carry significant risk, especially when sampled in patients with medical comorbidities or from critical areas such as the brainstem, prohibiting serial testing to monitor tumor evolution or treatment response. Furthermore, brain tumors might be inaccessible to biopsy, while, if reachable, the tissue specimens could be inadequate, show hypocellularity, abundant necrosis, or poor preservation that hamper subsequent molecular analysis [62, 65]. Of interest, both primary and metastatic CNS tumors display significant intra-tumor heterogeneity. This means that processing a small biopsy might not represent the whole tumor. Likewise, molecular testing of a primary extracranial cancer could be insufficient to guide treatment decisions for its CNS metastasis $[9,63$, 66, 67].

Liquid molecular analysis could facilitate tumor diagnosis, monitoring, and therapy selection, and overcome inherent problems related to a tissue biopsy. Similar to tissues, cancer mutational testing can be performed in body fluids such as the blood, urine, sputum, pleural fluid, and CSF [9, 68-70]. Even if it often fails to reach the diagnostic capacity of its tissue counterpart and lacks sufficient evidence of clinical validity and utility, the liquid biopsy is minimally invasive, cheaper than tissue biopsy, easier to obtain, and free from preservatives and fixatives. In addition, it depicts intra-tumor heterogeneity effectively and allows tumor follow-up with serial testing $[69,71,72]$. Any liquid counterpart including circulating tumor cells (CTCs), circulating tumor DNA (ctDNA), non-coding RNAs (e.g., miRNAs), or exosomes can be analyzed with diverse molecular techniques $[69,73]$. Of the latter, NGS is especially appealing, as it offers the capacity to examine comprehensively multiple cancer-related molecular alterations (point mutations, 
Table 2 Summary of published studies that highlight the value of CSF-based NGS analysis in CNS tumor patients

\begin{tabular}{|c|c|c|c|c|}
\hline First author, year & $\begin{array}{l}\text { CNS tumor types/number }(n) \text { of } \\
\text { patients involved in the analysis }\end{array}$ & NGS type & Main findings & $\begin{array}{l}\text { Refer- } \\
\text { ence }\end{array}$ \\
\hline Zhao et al. 2020 & $\begin{array}{l}\text { Primary (glioblastoma, diffuse } \\
\text { astrocytoma, anaplastic astrocytoma, } \\
\text { anaplastic oligodendroglioma)/n=17 }\end{array}$ & DNA-Seq & $\begin{array}{l}\text { NGS in CSF showed high concordance with tumor tissue } \\
\text { molecular analysis, albeit it revealed additional molecu- } \\
\text { lar alterations; lesions in proximity to the CSF space } \\
\text { were more likely to show ctDNA in their CSF molecular } \\
\text { analysis }\end{array}$ & {$[82]$} \\
\hline Li et al. 2019 & Primary (glioblastoma) $/ n=5$ & DNA-Seq & $\begin{array}{l}\text { NGS in CSF monitored CNS tumor molecular evolution } \\
\text { more accurately than in plasma }\end{array}$ & {$[83]$} \\
\hline Pan et al. 2019 & Primary (brainstem glioma) $/ n=57$ & DNA-Seq & $\begin{array}{l}\text { NGS in CSF identified alterations in most cases and } \\
\text { showed high concordance with tumor tissue molecular } \\
\text { analysis, while it revealed additional alterations; CSF } \\
\text { ctDNA revealed higher mutation detection rate than } \\
\text { plasma ctDNA; IDH1-mutant cancers exhibited favora- } \\
\text { ble, whereas H3F3A/HIST1H3B-mutant cancers poor } \\
\text { prognosis }\end{array}$ & [203] \\
\hline $\begin{array}{l}\text { Martínez-Ricarte et al. } \\
2018\end{array}$ & Primary (diffuse glioma) $/ n=20$ & DNA-Seq & $\begin{array}{l}\text { NGS in CSF facilitated molecular diagnosis and classifica- } \\
\text { tion of most diffuse gliomas tested, while sensitivity } \\
\text { dropped in low-grade tumors or in lesions non-adjacent } \\
\text { to the CSF space }\end{array}$ & {$[81]$} \\
\hline Miller et al. 2019 & Primary (diffuse glioma) $/ n=85$ & DNA-Seq & $\begin{array}{l}\text { NGS in CSF revealed ctDNA in about half of the patients, } \\
\text { while its presence was associated with dismal prognosis; } \\
\text { the mutational landscape of CSF ctDNA was highly } \\
\text { concordant with that of tumor tissue analysis, though } \\
\text { it revealed additional alterations that reflected tumor } \\
\text { heterogeneity and evolution; NGS in CSF showed higher } \\
\text { mutation detection rate than in plasma }\end{array}$ & [84] \\
\hline Mouliere et al. 2018 & $\begin{array}{l}\text { Primary (glioblastoma, oligodendro- } \\
\text { glioma, others) } / n=13\end{array}$ & DNA-Seq & $\begin{array}{l}\text { Whole genome sequencing was used to detect ctDNA in } \\
\text { CSF and identified copy number variations in } 38 \% \text { of } \\
\text { the cases; ctDNA concentration was dependent on tumor } \\
\text { grading and location (tumors of high-grade or adjacent } \\
\text { to the CSF space released more ctDNA) }\end{array}$ & {$[87]$} \\
\hline Wang et al. 2015 & $\begin{array}{l}\text { Primary (glioblastoma, medullo- } \\
\text { blastoma, anaplastic astrocytoma, } \\
\text { others) } / n=35\end{array}$ & DNA-Seq & $\begin{array}{l}\text { NGS in CSF revealed ctDNA in } 74 \% \text { of the cases, while } \\
\text { its detection was dependent on tumor grading (high- } \\
\text { grade tumors shed more ctDNA) and location (tumors } \\
\text { adjacent to the CSF space released more ctDNA) }\end{array}$ & {$[88]$} \\
\hline Duan et al. 2020 & Primary $($ glioblastoma $) / n=10$ & DNA-Seq & $\begin{array}{l}\text { NGS in CSF aided the molecular diagnosis and classifica- } \\
\text { tion of glioblastomas, while it also detected additional } \\
\text { alterations from tumor tissue analysis }\end{array}$ & [85] \\
\hline Grommes et al. 2019 & $\begin{array}{l}\text { Primary and secondary CNS } \\
\text { lymphomas } / n=15\end{array}$ & DNA-Seq & $\begin{array}{l}\text { NGS in CSF facilitated disease follow-up and monitored } \\
\text { response to therapy, while it detected ctDNA even when } \\
\text { imaging or CSF cytology were negative }\end{array}$ & [204] \\
\hline Zhao et al. 2020 & $\begin{array}{l}\text { Primary (glioblastoma) and meta- } \\
\text { static (lung, gastric, breast, etc.) } \\
\text { cancers } / n=58 \text { ( } 62 \text { CSF samples) }\end{array}$ & DNA-Seq & $\begin{array}{l}\text { All samples tested revealed mutations, the most com- } \\
\text { mon of which were TP53, EGFR, PTEN, CDKN2A; } \\
\text { CNVs of CDKN2A, CDK4, and MDM2 were the most } \\
\text { common ones detected; EGFR mutations found in CSF } \\
\text { were highly concordant with matched tissue molecular } \\
\text { analysis (in 9/10 patients) }\end{array}$ & {$[205]$} \\
\hline Baumgarten et al. 2020 & $\begin{array}{l}\text { Primary (glioblastoma, CNS lym- } \\
\text { phoma) and metastatic (breast, lung, } \\
\text { others) } / n=27\end{array}$ & $\begin{array}{l}\text { DNA and RNA- } \\
\text { Seq }\end{array}$ & $\begin{array}{l}\text { NGS in CSF identified alterations in the majority of the } \\
\text { tested cases, while some mutations were targetable } \\
\text { guiding cancer treatment; a number of cases revealed } \\
\text { increased TMB, which is known to be predictive of } \\
\text { response to immune checkpoint inhibitors; NGS in CSF } \\
\text { showed higher diagnostic sensitivity than imaging or } \\
\text { CSF cytology }\end{array}$ & {$[62]$} \\
\hline Kopkova et al. 2019 & $\begin{array}{l}\text { Primary (glioblastoma, low- } \\
\text { grade glioma, meningioma) and } \\
\text { metastatic } / n=70\end{array}$ & RNA-Seq & $\begin{array}{l}\text { NGS in CSF revealed differences in the miRNA levels of } \\
\text { the tested CNS tumors compared to their controls }\end{array}$ & [111] \\
\hline
\end{tabular}


Table 2 (continued)

\begin{tabular}{|c|c|c|c|c|}
\hline First author, year & $\begin{array}{l}\text { CNS tumor types/number }(n) \text { of } \\
\text { patients involved in the analysis }\end{array}$ & NGS type & Main findings & $\begin{array}{l}\text { Refer- } \\
\text { ence }\end{array}$ \\
\hline Pentsova et al. 2016 & $\begin{array}{l}\text { Primary (glioblastoma, anaplastic oli- } \\
\text { godendroglioma, others) and meta- } \\
\text { static (NSCLC, breast, melanoma, } \\
\text { others) } / n=53 \text { ( } 44 \text { with and } 9 \text { without } \\
\text { CNS involvement) }\end{array}$ & DNA-Seq & $\begin{array}{l}\text { NGS in CSF detected actionable alterations and identified } \\
\text { mechanisms of therapy resistance (e.g., EGFR T790M } \\
\text { mutation), while none of the nine samples with no } \\
\text { evidence of CNS involvement revealed any mutation; } \\
\text { NGS in CSF showed higher diagnostic sensitivity than } \\
\text { CSF cytology; ctDNA and mutation detection rated was } \\
\text { higher in CSF cytology positive than negative cases }\end{array}$ & [96] \\
\hline $\begin{array}{l}\text { De Mattos-Arruda } \\
\text { et al. } 2015\end{array}$ & $\begin{array}{l}\text { Primary (glioblastoma, medul- } \\
\text { loblastoma) and metastatic (lung, } \\
\text { breast) } / n=12\end{array}$ & DNA-Seq & $\begin{array}{l}\text { NGS in CSF showed higher concentration of ctDNA in } \\
\text { patients with CNS restricted disease and higher mutation } \\
\text { detection rate than in plasma, while it was more repre- } \\
\text { sentative of the CNS tumors' molecular profile; NGS } \\
\text { in CSF also facilitated diagnosis and monitored tumor } \\
\text { evolution and response to treatment }\end{array}$ & {$[107]$} \\
\hline Pan et al. 2015 & $\begin{array}{l}\text { Primary (meningioma, Schwannoma) } \\
\text { and metastatic (lung, melanoma, } \\
\text { breast, others) } / n=8\end{array}$ & DNA-Seq & $\begin{array}{l}\text { CSF molecular analysis with NGS and/or digital PCR } \\
\text { revealed mutations in } 7 / 8 \text { cases tested; ctDNA concen- } \\
\text { tration was higher in CSF than in plasma in patients with } \\
\text { low tumor systemic tumor burden }\end{array}$ & {$[86]$} \\
\hline Li et al. 2020 & Metastatic (NSCLC) $/ n=94$ & DNA-Seq & $\begin{array}{l}\text { EGFR mutations were found in } 79 / 94 \text { of the advanced } \\
\text { lung adenocarcinoma patients tested, while the presence } \\
\text { of CDK4, TP53, MET, CDKN2A, MYC, and SMAD4 } \\
\text { mutations was associated with poor prognosis }\end{array}$ & {$[206]$} \\
\hline Xing et al. 2020 & Metastatic $($ NSCLC) $/ n=38$ & DNA-Seq & $\begin{array}{l}\text { In this prospective study (APOLLO trial), significant } \\
\text { molecular heterogeneity was found between CSF and } \\
\text { plasma-based NGS testing; two patients with EGFR- } \\
\text { T790M in the CSF at baseline responded to osimertinib } \\
\text { treatment; the quantity of EGFR-T790M was reduced } \\
\text { after a 6-week treatment and patients exhibited a trend } \\
\text { towards improved progression free survival }\end{array}$ & [197] \\
\hline Zheng et al. 2020 & $\begin{array}{l}\text { Metastatic (NSCLC) } / n=45 \text { (cohort } 1) \\
\text { and } 35 \text { (cohort 2) }\end{array}$ & DNA-Seq & $\begin{array}{l}\text { In cohort 1, patients treated with osimertinib exhibited } \\
\text { differences in progression free survival based on the } \\
\text { EGFR mutation detected, while the coexistence of CD4 } \\
\text { or CDKN2A with EGFR mutations was associated } \\
\text { with shorter survival; in cohort 2, potential resistance } \\
\text { mechanisms to osimertinib were detected, such as the } \\
\text { C797S mutation }\end{array}$ & [198] \\
\hline Miao et al. 2020 & Metastatic (NSCLC) $/ n=23$ & DNA-Seq & $\begin{array}{l}\text { NGS in CSF revealed EGFR mutations in two patients } \\
\text { who exhibited EGFR-wild type in tissue-based molecu- } \\
\text { lar analysis }\end{array}$ & [207] \\
\hline Shen et al.., 2020 & Metastatic (NSCLC) $/ n=1$ & DNA-Seq & $\begin{array}{l}\text { NGS in CSF identified the mechanism of anti-EGFR } \\
\text { therapy resistance (EGFR T790M mutation) }\end{array}$ & {$[106]$} \\
\hline Ma et al. 2020 & Metastatic (NSCLC) $/ n=21$ & DNA-Seq & $\begin{array}{l}\text { NGS in CSF identified uncommon EGFR mutations that } \\
\text { guided cancer treatment decisions }\end{array}$ & {$[101]$} \\
\hline Ma et al. 2020 & Metastatic (NSCLC) $/ n=21$ & DNA-Seq & $\begin{array}{l}\text { NGS in CSF identified targetable alterations (e.g., EGFR } \\
\text { mutations) in the majority of the tested cases; the muta- } \\
\text { tion detection rate was higher in CSF than in plasma and } \\
\text { concordant to tumor tissue analysis }\end{array}$ & {$[100]$} \\
\hline Ma et al. 2019 & Metastatic (NSCLC) $/ n=1$ & DNA-Seq & $\begin{array}{l}\text { NGS in CSF identified an uncommon EGFR mutation } \\
\text { (G719A) that guided cancer treatment }\end{array}$ & [208] \\
\hline Liu et al. 2019 & Metastatic (NSCLC)/n=1 & DNA-Seq & $\begin{array}{l}\text { NGS in CSF identified the mechanism of anti-EGFR ther- } \\
\text { apy resistance (EGFR T790M and L718Q mutations) }\end{array}$ & {$[105]$} \\
\hline Zhao et al. 2019 & $\begin{array}{l}\text { Metastatic (lung, gastric, breast, } \\
\text { others) } / n=35\end{array}$ & DNA-Seq & $\begin{array}{l}\text { NGS in CSF showed higher diagnostic sensitivity than } \\
\text { imaging or CSF cytology }\end{array}$ & {$[98]$} \\
\hline Aldea et al. 2020 & Metastatic (NSCLC)/n=12 & DNA-Seq & $\begin{array}{l}\text { NGS in CSF showed higher mutation detection rate than } \\
\text { in plasma }\end{array}$ & [112] \\
\hline
\end{tabular}


Table 2 (continued)

\begin{tabular}{|c|c|c|c|c|}
\hline First author, year & $\begin{array}{l}\text { CNS tumor types/number }(n) \text { of } \\
\text { patients involved in the analysis }\end{array}$ & NGS type & Main findings & $\begin{array}{l}\text { Refer- } \\
\text { ence }\end{array}$ \\
\hline Villatoro et al. 2019 & $\begin{array}{l}\text { Metastatic (NSCLC, melanoma)/n=25 } \\
\quad(22 \text { CSF samples tested) }\end{array}$ & DNA-Seq & $\begin{array}{l}\text { Molecular analysis of CSF with NGS or PCR identified } \\
\text { actionable alterations and mechanisms of resistance that } \\
\text { guided cancer treatment decisions; CSF analysis showed } \\
\text { higher diagnostic sensitivity than CSF cytology and } \\
\text { mutation detection rate than plasma (it revealed altera- } \\
\text { tions in eight cases negative in the plasma analysis) }\end{array}$ & [97] \\
\hline Guo et al. 2019 & Metastatic (NSCLC) $/ n=1$ & DNA-Seq & $\begin{array}{l}\text { NGS in CSF identified EGFR alterations (19-Del, T790M) } \\
\text { that guided cancer treatment decisions }\end{array}$ & [209] \\
\hline Ge et al. 2019 & Metastatic (NSCLC) $/ n=29$ & DNA-Seq & $\begin{array}{l}\text { NGS in CSF identified actionable alterations and exhibited } \\
\text { higher mutation detection rate than plasma molecular } \\
\text { analysis }\end{array}$ & [99] \\
\hline Zheng et al. 2019 & $\begin{array}{l}\text { Metastatic (NSCLC with ALK } \\
\text { rearrangement) } / n=11\end{array}$ & DNA-Seq & $\begin{array}{l}\text { NGS in CSF identified driver alterations and mechanisms } \\
\text { of treatment resistance, exhibiting higher mutation } \\
\text { detection rate than plasma; ALK rearrangement detec- } \\
\text { tion was concordant between CSF and tumor tissue } \\
\text { molecular analysis }\end{array}$ & {$[102]$} \\
\hline Song et al. 2019 & $\begin{array}{l}\text { Metastatic (NSCLC) } / n=1 \text { (multiple } \\
\text { CSF samples) }\end{array}$ & DNA-Seq & $\begin{array}{l}\text { NGS in CSF exhibited higher mutation detection rate than } \\
\text { plasma molecular analysis and monitored response to } \\
\text { treatment }\end{array}$ & [110] \\
\hline Ballester et al. 2018 & Metastatic (melanoma) $/ n=7$ & DNA-Seq & $\begin{array}{l}\text { Molecular analysis of CSF with NGS or digital PCR } \\
\text { identified melanoma-related alterations, even when CSF } \\
\text { cytology was negative for tumor cells }\end{array}$ & {$[95]$} \\
\hline Li et al. 2018 & $\begin{array}{l}\text { Metastatic (EGFR-mutant } \\
\text { NSCLC) } / n=26\end{array}$ & DNA-Seq & $\begin{array}{l}\text { NGS in CSF identified actionable alterations and } \\
\text { mechanisms of resistance that guided cancer treatment } \\
\text { decisions; it also exhibited higher mutation detection } \\
\text { rate than plasma, while the EGFR mutation detection } \\
\text { was concordant between CSF and primary tumor tissue } \\
\text { molecular analysis }\end{array}$ & {$[104]$} \\
\hline Siravegna et al. 2017 & $\begin{array}{l}\text { Metastatic (HER2-positive breast } \\
\text { cancer) } / n=1 \text { (two CSF samples } \\
\text { tested) }\end{array}$ & DNA-Seq & $\begin{array}{l}\text { Molecular analysis of CSF with NGS or digital PCR } \\
\text { revealed progression and poor response to treatment of } \\
\text { the CNS metastasis, in contrast to the plasma analysis }\end{array}$ & [109] \\
\hline Fan et al. 2018 & $\begin{array}{l}\text { Metastatic (EGFR-mutant } \\
\text { NSCLC) } / n=11\end{array}$ & DNA-Seq & $\begin{array}{l}\text { Even if the EGFR mutation detection rate was concordant, } \\
\text { significant heterogeneity was identified between CSF } \\
\text { and primary tumor tissue molecular analysis; alterations } \\
\text { in genes involved in cell-cycle regulation and DNA } \\
\text { repair were suggested to drive CNS metastasis }\end{array}$ & {$[42]$} \\
\hline Jiang et al. 2017 & Metastatic (NSCLC) $/ n=19$ & DNA-Seq & $\begin{array}{l}\text { NGS of CSF-derived CTCs identified actionable muta- } \\
\text { tions and potential mechanisms of treatment resistance, } \\
\text { while it was concordant with tumor tissue molecular } \\
\text { analysis }\end{array}$ & [103] \\
\hline Ying et al. 2019 & Metastatic (NSCLC) $/ n=72$ & DNA-Seq & $\begin{array}{l}\text { NGS in CSF showed higher concentration of ctDNA and } \\
\text { mutation detection rate than in plasma; however, T790M } \\
\text { mutations were detected at a lower rate }\end{array}$ & [113] \\
\hline Li et al. 2016 & $\begin{array}{l}\text { Metastatic (melanoma) } / n=1 \text { ( } 6 \mathrm{CSF} \\
\text { samples tested) }\end{array}$ & DNA-Seq & $\begin{array}{l}\text { Molecular analysis of CSF with digital PCR and NGS } \\
\text { facilitated tumor follow-up and monitored its response to } \\
\text { treatment, highlighting molecular heterogeneity between } \\
\text { the pretreatment and recurrence samples }\end{array}$ & [108] \\
\hline
\end{tabular}

$C S F$ cerebrospinal fluid, $C N S$ central nervous system, ctDNA circulating tumor DNA, CTCs circulating tumor cells, $N G S$ next-generation sequencing, NSCLC non-small cell lung cancer, miRNA microRNA, PCR polymerase chain reaction, TMB tumor mutational burden

insertions, deletions, copy number variations, and gene rearrangements) in a single run [74].

This section describes the recent evidence regarding CSFbased NGS testing in patients with primary or metastatic CNS tumors. We summarize this evidence in Table 2 and illustrate its importance in Fig. 2.

\subsection{Primary CNS Cancers}

Regarding primary CNS cancers, GLOBOCAN estimated 296,851 ( $1.6 \%$ of all sites) new cases and 241,037 deaths (2.5\% of all sites) globally in 2018 [75]. Gliomas represent the most common primary CNS malignancy, while 
glioblastomas account for most gliomas in the adults, exhibiting low resectability and high recurrence rates [64]. In children, CNS tumors follow leukemias in incidence yet they lead all pediatric cancers in morbidity and mortality; of them, the embryonal tumor medulloblastoma is the most common malignant lesion [76]. Prognosis and management of primary CNS tumors largely depend on their grade. Grading measures diverse tumor characteristics including cellular atypia, mitoses, necrosis, and endothelial proliferation. The higher the grade, the worse the prognosis generally is; for instance, glioblastomas and medulloblastomas are both grade IV tumors of dismal prognosis [60].

Molecular profiling of CNS tumors is essential for their accurate diagnosis and should be performed together with morphologic evaluation, according to the latest WHO classification [60]. Gliomas are classified as IDH-mutant and IDH-wild type, as their prognosis differs significantly, being worse in the wild type. In addition, $1 \mathrm{p} / 19 \mathrm{q}$ co-deletion is a molecular alteration characterizing oligodendrogliomas, while a diffuse glioma of lower grade (II or III) and an IDHwild type status is upgraded to "molecular glioblastoma" (integrated grade IV glioma) when alterations such as EGFR amplification or TERT promoter alterations are found [60, $64,77]$. TERT promoter mutation is associated with a dismal prognosis, while MGMT promoter methylation is associated with a favorable response to chemotherapy and prolonged survival $[64,78,79]$. Likewise, hypermutation after chemotherapy is a major factor of tumor progression and therapy resistance $[64,80]$.

CSF-based molecular analysis in primary CNS tumor patients could provide valuable information concerning accurate diagnosis and classification, alterations linked with prognosis and therapy selection, tumor evolution, and response to treatment (Table 2). Besides testing 20 tissue biopsies and CSFs from glioma patients, Martinez-Ricarte et al. also analyzed 648 diffuse gliomas from the TCGA Atlas and developed an NGS platform that can genotype seven genes (including IDH1, IDH2, TP53, TERT, and $\mathrm{H} 3 \mathrm{~F} 3 \mathrm{~A}$ ); this platform could facilitate the classification of gliomas with CSF ctDNA, avoiding the risk of invasive sampling [81]. Zhao et al. applied targeted NGS and identified driver mutations from the CSF ctDNA in both newly diagnosed and relapsed glioma patients; of interest, the concordance rate with their matched tumor tissue samples in this study was high [82]. As CSF sampling is minimally invasive, CSF-derived ctDNA analysis is not only promising for defining gliomas' initial molecular signature but also for subsequent serial testing to monitor potential tumor progression [83, 84].

Concerning the value of NGS as an element of CSF molecular analysis, several teams have compared the molecular signatures of the CSF-derived ctDNA to the tissuederived DNA. In brief, CSF-based NGS analysis was largely concordant with the tissue-based analysis. Furthermore, it also spotted additional mutations, reflecting intratumoral heterogeneity, while it overcame the under-sampling bias inherent to small biopsies [9, 82, 84-86]. NGS diagnostic capacity was directly correlated to the tumor grade and location. High-grade tumors (e.g., glioblastomas) with a location next to the CSF space were more likely to excrete ctDNA into the CSF circulation $[81,82,87,88]$. Likewise, NGS in CSF exhibited superior performance to plasma molecular analysis, revealing higher mutation detection rates $[83,84$, 86].

\subsection{Metastatic CNS Cancers}

Metastatic spread is a frequent complication and substantial cause of mortality in patients with a cancer that first develops outside the CNS, most commonly in the lung, breast, or skin (melanoma). Prognosis in such patients is generally poor, hence there is an emerging need to integrate molecular data into personalized treatment strategies [27]. Recent guidelines recommend that patients with advanced non-small-cell lung cancer (NSCLC) should undergo predictive biomarker testing for potential EGFR, ALK, ROS1, $B R A F$ molecular alterations, as targeted therapies exist for them. In addition, mutations such as the EGFR T790M are associated with resistance to therapy $[63,89,90]$. Likewise, patients with breast cancer and melanoma should be tested for the presence of $H E R 2$ amplification or BRAF V600E mutation to assess their prognosis and evaluate their eligibility for trastuzumab or the BRAF inhibitor vemurafenib, respectively $[63,91]$. While delivery of traditional chemotherapy into the CNS lesion is significantly limited by the blood-brain barrier, targeted therapies seem to outweigh chemotherapy in terms of efficacy and safety [62, 63]. As the metastatic cancer molecular profile might differ from its primary counterpart, testing of only the primary site could be insufficient as it ignores heterogeneity and tumor evolution. In fact, the European Association of Neuro-Oncology recommends that, even if a cancer is previously assessed in its primary extracranial location, predictive biomarker testing should also be performed in the CNS metastatic site [62, 63, 91, 92].

Similar to primary CNS tumors, the application of CSFbased NGS testing in metastatic tumors could also facilitate diagnosis and prognosis, identify targetable mutations, assess intra-tumor heterogeneity, monitor tumor evolution and therapy response, and identify mechanisms of drug resistance (Table 2). Diagnosis and follow-up of metastatic CNS lesions are typically performed with neuroimaging and CSF cytology; however, the latter suffer from low sensitivity $[93,94]$. NGS was found to outweigh the diagnostic performance of imaging and cytology in terms of sensitivity for the detection of brain metastases [62, 95-98]. It was 


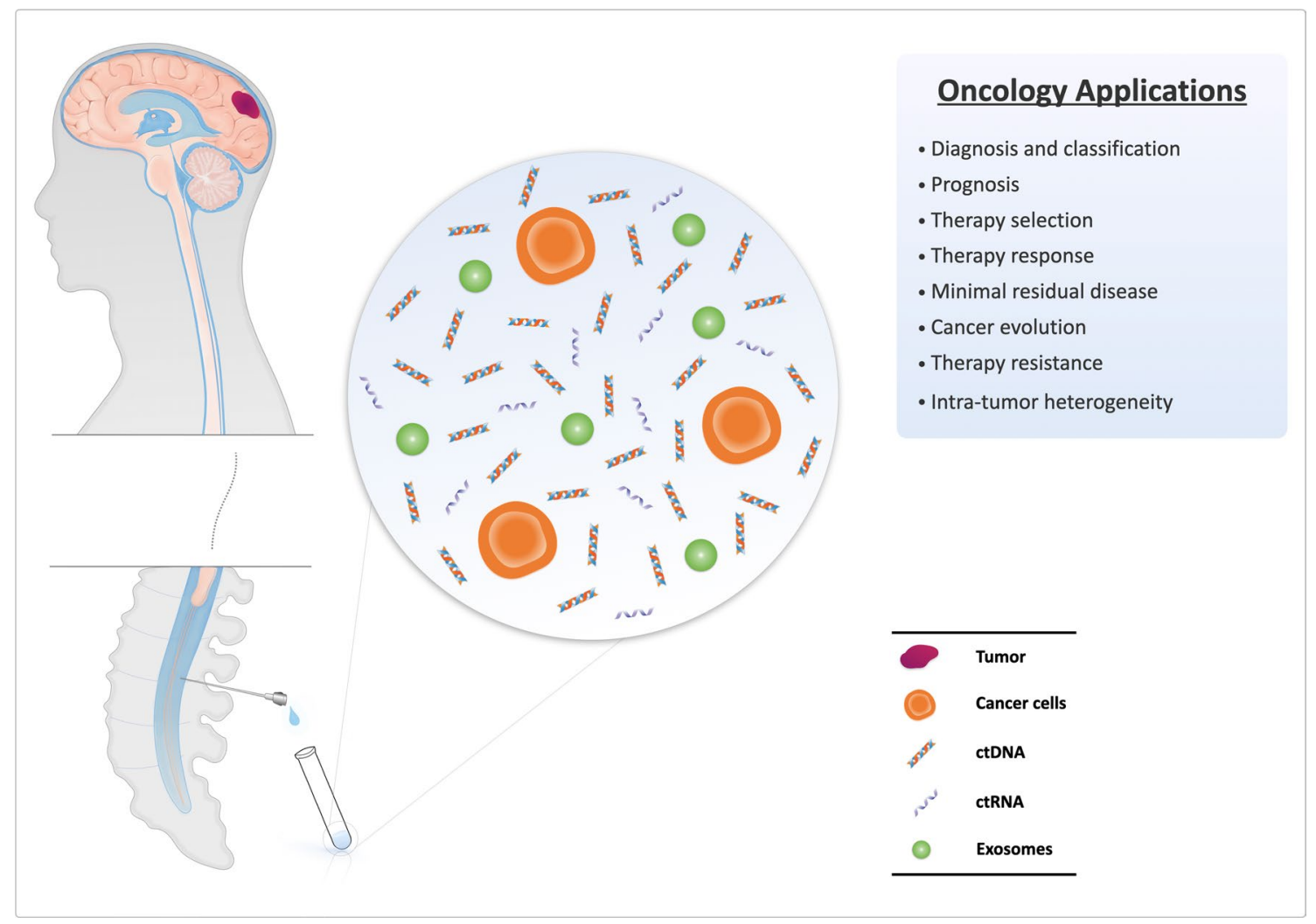

Fig. 2 The role of CSF-based next-generation sequencing (NGS) in the evaluation of primary and metastatic CNS cancers. ctDNA, circulating tumor DNA; CSF cerebrospinal fluid, CNS central nervous system, $c t R N A$ circulating tumor RNA

also able to detect targetable mutations in metastatic lung (e.g., EGFR, ALK, or ROS1) [62, 96, 97, 99-102], melanoma [95-97], and breast cancer [96], also identify mechanisms of acquired resistance to therapy, such as the EGFR T790M mutation [96, 103-106]. Von Baumgarten et al. tested the CSF of 27 patients with metastatic and primary CNS tumors and reported that, by applying NGS to analyze the CSFderived ctDNA, they could identify targetable mutations and change the treatment strategy in some of their patients. They also identified six cases with several molecular alterations suggesting high tumor mutational burden (TMB), which is known to be predictive of response to immune checkpoint inhibitors [62]. Many groups have also suggested the potential value of CSF-based NGS testing to follow-up patients with brain metastases and evaluate their response to treatment or identify disease progression, which could be spotted earlier compared to clinical presentation, imaging, or CSF cytology [42, 107-110]. While most studies have used ctDNA for their NGS experiments, Kopkova et al. demonstrated differences in the miRNA levels of the CNS tumors compared to controls by examining the CSF samples of 70 patients with both metastatic and primary lesions [111].
Similar to primary CNS tumors, CSF-based NGS testing was also largely concordant with tissue molecular analysis in metastatic CNS cancer patients, while it further detected additional mutations that were potentially missed due to tissue under-sampling. [9, 42, 100, 102-104]. Likewise, NGS in CSF was more sensitive than plasma molecular analysis in metastatic cancer patients $[86,97,100,102,104,107$, 109, 110, 112, 113].

\section{Neuroimmunological and Neurodegenerative Disorders}

Genetics of neuro-psychiatric disorders involve diseases in the CNS controlled by either monogenic inheritance or complex polygenic inheritance and associated with an interplay of genetic risk and environmental influence [114, 115]. The rapid advancement of molecular testing during the last decades with NGS and genome-wide association studies (GWAS) has revolutionized the area, facilitating the research of disease mechanisms and enhancing the accuracy of diagnosis. Genetic studies in neurologic and psychiatric 
disorders are focused on the investigation of the genome, the transcriptome, or the epigenome. While for disorders with monogenic type of inheritance, testing for genomic variations in the peripheral blood is adequate, for diseases with complex polygenic inheritance transcriptome and epigenome analysis is equally important [116]. Brain tissue from autopsy or biopsy and peripheral blood are the most commonly used sources for this kind of testing, but during recent years the CSF has also been investigated [117]. To date, the CSF has been used as a source of genetic material for NGS studies, mainly for transcriptomics in autoimmune neurological disorders and neurodegenerative disorders. The characteristics of these studies are summarized in Table 3 and Fig. 3. NGS has also been used in CSF of patients with acute ischemic stroke and several brain-enriched miRNAs have been detected 3 days after stroke, mostly associated with large ischemic strokes [118]. Finally, in recent years, the genetic basis of psychiatric disorders has begun to be identified [116, 119-122], but the only NGS study in the CSF contacted so far is related to the detection of known and novel viruses in patients with schizophrenia [123].

\subsection{Neuroimmunological Disorders}

Multiple sclerosis (MS) is the most common autoimmune disease of the CNS with still unknown etiology. The interaction between genetic risk factors and environmental influence is believed to be the key feature of the disease pathogenesis [124]. Initial genetic studies revealed strong associations in MS for genes within the major histocompatibility complex (MHC) including the human leukocyte antigen (HLA) class I and II [125-127]. More recently, during the last two decades, the advent of GWASs revealed more than 200 genetic risk variants for MS located in introns or exons, most of which reside in non-MHC regions [128-131]. The functional consequences of these variants are not yet fully understood, apart from a small number that are proven to be implicated in the regulation of the immune system [132-135]. On the way to better characterize the pathogenetic cascade that is related to the genetic risk variants, transcription and epigenetic mechanisms have been investigated as well, adding meaningful information to pathway analysis [135-139]. To this extent, the genetic material isolated from CSF, tested with NGS, provides valuable information both for research and for diagnostic purposes.

$\mathrm{B}$ and $\mathrm{T}$ cells have a central role in the pathogenesis of MS, as they interact and infiltrate the CNS causing local pathology and demyelination [140]. Lymphocytes of MS patients seem to undergo extensive clonal expansion inside the CNS [141, 142], but there is still a long debate about the mechanisms and the location of B- and T-cell activation, the invasion of CNS, their maturation and their reactivation. Findings of NGS in B and T cells of the peripheral blood, the CSF and the brain lesions have largely contributed to the understanding of the disease pathogenesis. Initial NGS studies on the repertoire of IgG heavy chain variable region genes showed that $\mathrm{B}$ cells may experience ongoing stimulation and maturation in the CNS, but they exchange across the blood-brain barrier and they can be identified in the peripheral blood [141, 143, 144]. Another NGS study, however, claimed that most of their maturation takes place outside the CNS in the draining cervical lymph nodes [145]. Further NGS analysis of CSF-derived B cells from MS patients has shown rearranged IgG variable heavy chain family 4 genes, suggestive of pronounced affinity maturation in the CNS, a feature that can be used as a biomarker for the diagnosis of MS [146-149]. In line with these findings, other studies revealed persistence over time of intrathecal oligoclonal B cells and IgG [150] and intrathecal somatic hypermutation of IgM chains that are not observed in the peripheral blood [151]. Similarly, for T cells, initial NGS studies have shown that $\mathrm{CD} 8+$ and $\mathrm{CD} 4+$ cells isolated from brain autopsy lesions can be also found in the CSF [152], and that clonally expanded CD8+ T cells are located in brain lesions, the CSF, and the peripheral blood [153]. However, further high-throughput sequencing of the T-cell receptor repertoires of the CSF revealed that they are largely distinct from the blood in MS patients [154, 155], and that there is intrathecal enrichment of EBV-reactive CD8+ T cells and CD8+CD161 T cells [156, 157]. Interestingly, NGS of $\mathrm{CD} 8+$ and CD4+ T-cell receptor gene repertoires from CSF was used recently to support the diagnosis of MS [158] and to test the efficacy of treatment with autologous hematopoietic stem cell transplantation [159]. Furthermore, recently single-cell transcriptomics revealed increased transcriptional diversity in blood, and increased cell-type diversity in CSF including a higher abundance of cytotoxic phenotype $\mathrm{T}$ helper cells clonally expanded B cell in MS [160, 161].

Neuromyelitis optica (NMO) is a rare autoimmune disease of the CNS characterized by inflammatory response against aquaporin-4 (AQP4). A recent study comparing NGS analysis of B cells in the CSF and the peripheral blood revealed that CSF AQP4-specific B cells are closely related to an expanded population of double negative $B$ cells of the peripheral blood that may undergo maturation within the CNS [162].

\subsection{Neurodegenerative Disorders}

During the past few decades, tremendous progress on the understanding of neurodegenerative diseases has been achieved. However, neurodegenerative diseases constitute a heterogenic cluster with various degrees of overlapping in terms of clinical features, imaging findings, serum and CSF parameters, pathological characteristics, and associated genes [163-168]. While pathological brain changes 
Table 3 Characteristics of NGS studies in CSF in neuroimmunological and neurodegenerative diseases

\begin{tabular}{|c|c|c|c|c|}
\hline First author, ycear & Disease/cases $(n)$ & NGS type & Main findings & Reference \\
\hline Bankoti et al. 2014 & MS $(n=5)$ & RNA-Seq & $\begin{array}{l}\text { Oligoclonal bands are not merely the terminal result of a targeted } \\
\text { immune response in MS but represent a component of active B } \\
\text { cell immunity that is dynamically supported on both sides of the } \\
\text { blood-brain barrier }\end{array}$ & [143] \\
\hline Palanichamy et al, 2014 & $\operatorname{MS}(n=8)$ & RNA-Seq & $\begin{array}{l}\text { Identified peripheral memory B cells, plasma cells/plasmablasts, and } \\
\text { B cells that had an immune connection to the CNS compartment }\end{array}$ & [144] \\
\hline von Büdingen et al. 2012 & MS $(n=6)$ & RNA-Seq & $\begin{array}{l}\text { Identified clonally related B cells that participate in robust } \\
\text { bidirectional exchange across the blood-brain barrier }\end{array}$ & [141] \\
\hline Stern et al. 2014 & MS $(n=5)$ & DNA-Seq & $\begin{array}{l}\text { The majority of the B cells associated with MS maturation takes } \\
\text { place outside the CNS }\end{array}$ & [145] \\
\hline Rounds et al. 2014 & MS $(n=8)$ & DNA-Seq & $\begin{array}{l}\text { A pattern of mutations in the antibody genes of CSF B cells can } \\
\text { identify patients who have RRMS and patients who will convert } \\
\text { to RRMS }\end{array}$ & [146] \\
\hline Rounds et al. 2015 & MS $(n=13)$ & DNA-Seq & $V H 4$ gene mutations of CSF B cells can identify patients with RRMS & [147] \\
\hline Johansen et al. 2015 & MS $(n=10)$ & DNA-Seq, RNA-Seq & $\begin{array}{l}\text { Immunoglobulin heavy-chain variable gene transcipts were identified } \\
\text { in blood B cells and clonally related CSF B cells }\end{array}$ & [148] \\
\hline Ostmeyer et al. 2017 & $\operatorname{MS}(n=71)$ & DNA-Seq & $\begin{array}{l}\text { VH4 gene mutations of CSF B cells can be used as a statistical clas- } \\
\text { sifier in the diagnosis of RRMS }\end{array}$ & [149] \\
\hline Tomescu-Baciu et al. 2019 & $\operatorname{MS}(n=2)$ & RNA-Seq & Persistence overtime of intrathecal oligoclonal B cells and $\operatorname{IgG}$ & {$[150]$} \\
\hline Beltrán et al. 2014 & MS $(n=12)$ & RNA-Seq & $\begin{array}{l}\text { Intrathecal somatic hypermutation of IgM chains that are not } \\
\text { observed in the peripheral blood }\end{array}$ & [151] \\
\hline Planas et al. 2015 & $\operatorname{MS}(n=1)$ & RNA-Seq & $\begin{array}{l}\text { CD8+ and CD4+ cells isolated from brain autopsy lesions can be } \\
\text { also found in the CSF }\end{array}$ & [152] \\
\hline Salou et al. 2015 & MS $(n=7)$ & RNA-Seq & $\begin{array}{l}\text { Clonally expanded CD } 8+\mathrm{T} \text { cells are located in brain lesions, the } \\
\text { CSF and the peripheral blood }\end{array}$ & [153] \\
\hline Lossius et al. 2014 & MS $(n=10)$ & RNA-Seq & $\begin{array}{l}\text { There is intrathecal enrichment of EBV-reactive CD8+ T cells and } \\
\text { CD8+CD161 T cells }\end{array}$ & [156] \\
\hline Nicol et al. 2018 & MS $(n=90)$ & RNA-Seq & $\begin{array}{l}\text { There is intrathecal enrichment of EBV-reactive CD8+ T cells and } \\
\text { CD8+CD161 T cells }\end{array}$ & [157] \\
\hline Gerdes et al. 2016 & $\operatorname{MS}(n=1)$ & RNA-Seq & $\begin{array}{l}\text { NGS of CD8+ and CD4+ T-cell receptor genes repertoires from } \\
\text { CSF may be used to support the diagnosis of MS }\end{array}$ & [158] \\
\hline Harris et al. 2020 & MS $(n=24)$ & RNA-Seq & $\begin{array}{l}\text { NGS of CD8+ and CD4+ T-cell receptor genes repertoires from } \\
\text { CSF may be used to test the efficacy of treatment with autologous } \\
\text { hematopoietic stem cell transplantation }\end{array}$ & [159] \\
\hline Schafflick et al. 2020 & $\operatorname{MS}(n=60)$ & RNA-Seq & $\begin{array}{l}\text { Increased cell type diversity in CSF, including abundance of cyto- } \\
\text { toxic phenotype Thelper cells in MS }\end{array}$ & {$[160]$} \\
\hline Ramesh et al. 2020 & $\operatorname{MS}(n=12)$ & RNA-Seq & $\begin{array}{l}\text { Clonally expanded B cell in MS were associated with inflammation, } \\
\text { blood-brain barrier breakdown, and intrathecal Ig synthesis. }\end{array}$ & [161] \\
\hline Kowarik et al. 2017 & $\operatorname{NMOSD}(n=7)$ & DNA-Seq & $\begin{array}{l}\text { AQP4-specific B cells are closely related to an expanded popula- } \\
\text { tion of double negative B cells of the peripheral blood that may } \\
\text { undergo maturation within the CNS }\end{array}$ & {$[162]$} \\
\hline Ostmeyer et al. 2017 & $\operatorname{MS}(n=71)$ & DNA-Seq & $\begin{array}{l}\text { VH4 gene mutations of CSF B cells can be used as a statistical clas- } \\
\text { sifier in the diagnosis of RRMS }\end{array}$ & [149] \\
\hline Jain et al, 2019 & $\mathrm{AD}(n=17)$ & RNA-Seq & $\begin{array}{l}\text { miRNAS and piRNAs are associated with the progression of MCI } \\
\text { to } A D\end{array}$ & [70] \\
\hline Burgos et al. 2014 & $\begin{array}{l}\mathrm{PD}(n=57) \\
\mathrm{AD}(n=62)\end{array}$ & RNA-Seq & $\begin{array}{l}\text { miRNAs from the periphery and the CSF may be used to predict } \\
\text { disease progression }\end{array}$ & [23] \\
\hline Hossein-Nezhad et al. 2016 & $\mathrm{PD}(n=27)$ & RNA-Seq & $\begin{array}{l}\text { CSF miRNAs related to } P A R K 7, L R R K 2, S N C A \text { genes could be used } \\
\text { as potential biomarkers in PD }\end{array}$ & [65] \\
\hline Otake et al. 2019 & $\operatorname{ALS}(n=4)$ & RNA-Seq & $\begin{array}{l}\text { Presence of mRNAs of genes associated with ubiquitin-proteasome, } \\
\text { unfolded protein and oxidative stress pathways in CSF of ALS } \\
\text { patients }\end{array}$ & [120] \\
\hline
\end{tabular}

$N G S$ next-generation sequencing, $C S F$ cerebrospinal fluid, $M S$ multiple sclerosis, $R R M S$ relapsing-remitting multiple sclerosis, $E B V$ EpsteinBarr virus, NMOSD neuromyelitis optica spectrum disorders, $A Q P 4$ aquaporin-4, $A D$ Alzheimer disease, miRNA microRNA, EOAD early-onset $\mathrm{AD}, M C I$ mild cognitive impairment, piRNA PIWI-interacting RNA, $P D$ Parkinson disease, $A L S$ amyotrophic lateral sclerosis 


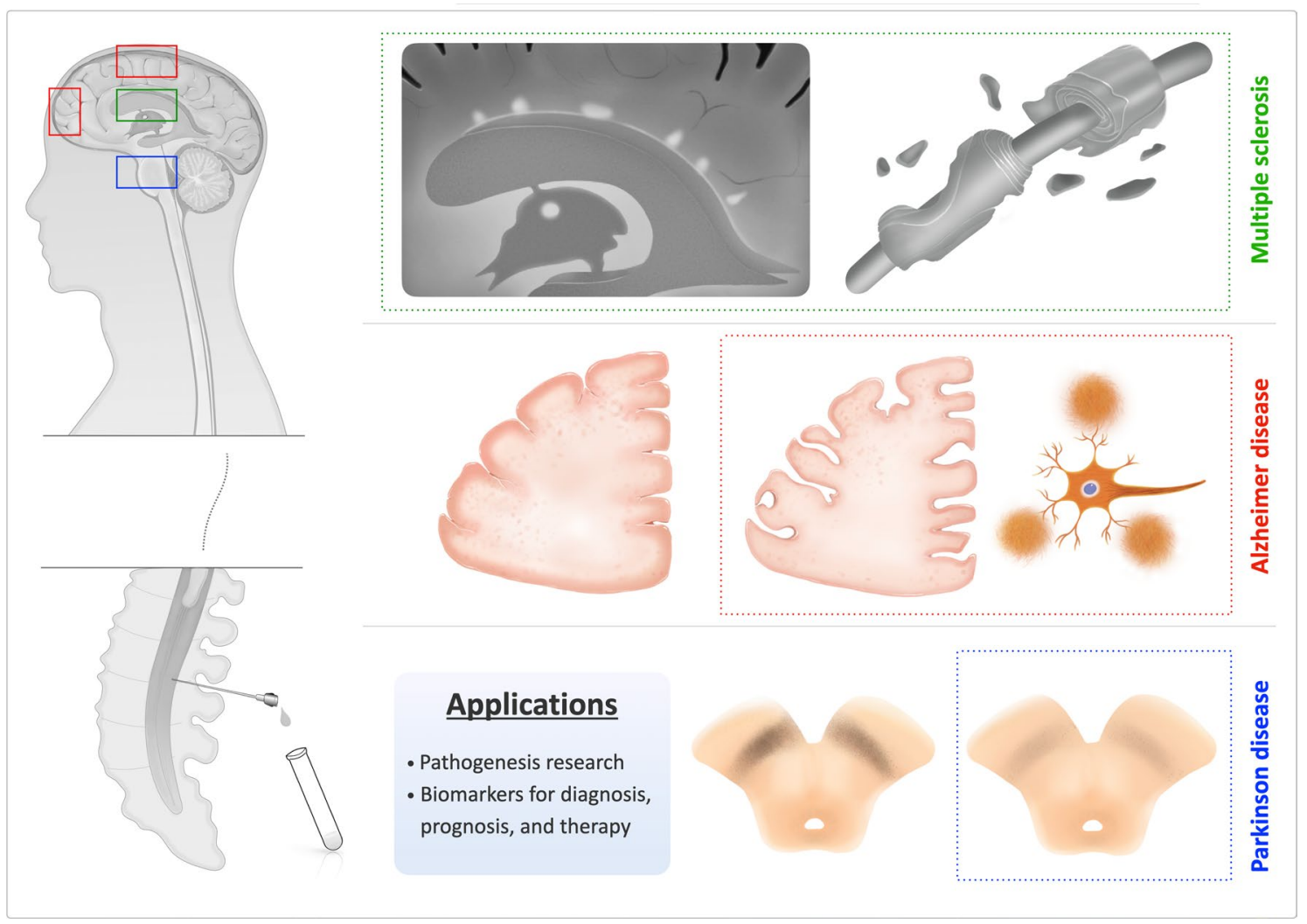

Fig. 3 The role of CSF-based next-generation sequencing (NGS) in the diagnosis on neurodegenerative and neuroinflammatory diseases. CSF cerebrospinal fluid, $C N S$ central nervous system, $C N S$ central nervous system, $C N S$ central nervous system

may begin up to 30 years before the symptomatic phase in some of them [169, 170], only symptomatic treatments exist, all trying to counterbalance the neurotransmitter disorganization and none to hamper disease progression [171]. Furthermore, symptomatic treatments are effective only in the early disease stages [172]. Thus, early detection is crucial, but accurate diagnosis is a real challenge for the clinical neurologist, and it is not uncommon for the diagnosis to be established only post-mortem [173].

Alzheimer disease (AD) is the most common neurodegenerative disease. While $\mathrm{AD}$ is characterized by an age-related pathology, there are a variety of genes related to early-onset $\mathrm{AD}$ [174]. Among them, the most common is Allele 4 of apolipoprotein E (ApoE4), which is also the most important risk factor for sporadic AD [175]. The pathological hallmarks of $\mathrm{AD}$ are amyloid plaques and neurofibrillary tangles in brain tissue, reflected by a decrease in amyloid- $\beta$ peptide 1-42 (A $\beta 42)$, and increase in total Tau and phosphorylated Tau protein (p-tau) in CSF [176]. A $\beta 42$ is considered to be responsible for triggering a downstream that leads to Tau accumulation within neurons and, eventually, apoptosis [177]. Nevertheless, several other factors are implicated in AD pathogenesis, including mitochondrial, metabolic, inflammatory, and oxidative stress mechanisms
[178-181]. Recently, genetic studies in the CSF significantly contributed to the clarification of these pathways. MicroRNAs (miRNAs) seem to play an important role in abnormal gene expression for genes associated with AD pathology [174]. During the past few years, several studies have identified with RT-PCR numerous miRNAs implicated in AD pathogenesis, some of them detected in the CSF [182-185]. Additionally, transcriptome analysis of the CSF with NGS in AD managed to identify a variety of miRNAs and other small noncoding RNAs considered to be candidate biomarkers for $\mathrm{AD}$, while changes in miRNA expression were shown to correlate well with aspects of disease severity [186, 187].

Parkinson disease (PD) is the second most common neurodegenerative disease. It is characterized by motor symptoms, including bradykinesia, rigidity, and tremor, along with non-motor symptoms [169]. Its pathological hallmark is the progressive neuronal loss in the substantia nigra pars compacta due to accumulation of protein $\alpha$-synuclein into cytoplasmic inclusions [188]. From there, the pathology spreads to the basal ganglia and the brain cortex. This could explain the variety of motor and non-motor symptoms associated with PD, including REM-sleep behavior disorder, dysautonomia, depression, and, finally, dementia. Thus, similar to AD patients, PD patients also seem to express 
cognitive impairment, especially in the late stages of the disease, when advanced neurodegeneration has taken place $[165,166]$. This common disease progression, at least in the late stages of the PD, implies that $\mathrm{AD}$ and PD might share some common pathological features [167, 168]. So, the initiative of transcriptomics in $\mathrm{AD}$ has also motivated similar studies in PD. Burgos et al. compared miRNAs from the periphery and the CSF from patients with PD or AD and normal controls [187]. They found miRNA dysregulation in both $\mathrm{AD}$ and PD patients compared to normal controls. Interestingly, some of the miRNAs were differentially expressed in both PD and AD, while others were expressed only in AD or PD patients. After that, a few other miRNAs in the CSF have been identified as potential PD biomarkers. Some of them were related to genes that are associated with PD, such PARK7, LRRK2, and SNCA [189].

Amyotrophic lateral sclerosis (ALS) is another neurodegenerative disease, whose main characteristic is the progressive loss of upper and lower motor neurons, commonly in association with cognitive and behavioral symptoms [190]. Indeed, an association between ALS and certain types of frontotemporal dementia has been well established [164]. Otake et al., using NGS transcriptome technology, analyzed exosomal mRNAs in human CSF [191]. In comparison with CSF of normal controls, 543 genes were found to have mutations and most of them were involved in the ubiquitin-proteasome, unfolded protein, and oxidative stress pathways.

\section{Discussion}

Several studies suggest that CSF-based NGS has a role in the evaluation of infectious and neoplastic CNS diseases, while evidence concerning immunological and neurodegenerative diseases is at a more rudimentary level. NGS is a highthroughput, fast, and sensitive, albeit labor-intensive and costly, technique able to process multiple nucleic acid fragments in parallel and within a single run, at both genomic (DNA) or transcriptomic levels, without requiring prior knowledge of the exact nucleic acid sequence(s). This contrasts with PCR applications, which entail a hypothesis of potential targets in order to select the most suitable primers $[10,192]$. Of interest, most CSF-based next-generation transcriptomic analyses applying RNA-Seq have been reported in MS, AD, or PD studies (Table 3), whereas only a minority of oncology studies have utilized this methodology instead of DNA-Seq (Table 2). Targeted NGS is often used in oncological applications [11], and mNGS in microbiological applications [12]. The latter could especially be of value when conventional, less sensitive microbiologic methodssuch as morphologic evaluation (e.g., with Gram stain), cultures, or serologic testing-fail to diagnose the cause of a CNS infection, delaying treatment and impacting clinical outcome [4, 5]. In addition, because of its high-throughput nature, mNGS could help characterize genes responsible for antimicrobial drug resistance [29] or identify pathogens causing outbreaks [28]. However, despite its reported high diagnostic accuracy, mNGS clinical application is still at an early phase and there are several limitations [31], while most evidence has been derived from small retrospective studies [32].

The application of NGS in the CSF can facilitate diagnosis and classification, prognosis, selection of therapy, and follow-up of primary and metastatic CNS tumors (Fig. 1). Of interest, CSF liquid biopsy could supplement or even replace tissue-based molecular analysis in the right clinical setting (e.g., patients with severe comorbidities, CNS tumors in critical or inaccessible locations, indication for sequential sampling to monitor evolution or therapy response), as it minimizes operational risk, is cheaper, and provides molecular signatures concordant to tissue analysis $[9,62,73]$. In addition, CSF liquid biopsy does not suffer from the inherent problems of tissue biopsy that commonly hamper subsequent molecular analysis, such as inadequacy and formalin fixation, and could depict intra-tumor heterogeneity more comprehensively, especially when compared to small biopsies [62, 63, 66, 193]. Likewise, it exhibits higher sensitivity to detect leptomeningeal metastases than imaging or CSF cytology [62, 95-98]. Evidence suggests that CSF liquid biopsy should be favored over its plasma counterpart when evaluating a CNS tumor, either primary or metastatic, as it shows a higher concentration of ctDNA and a higher mutation detection rate, and it depicts the CNS lesion molecular profile more accurately, especially when dealing with brain metastases. Plasma liquid biopsy exhibits reduced diagnostic capacity since the blood-brain-barrier hampers the shedding of CNS tumor-derived genetic material into the blood. In addition, as blood contains more normal circulating DNA derived from its higher population of non-malignant cells than the paucicellular CSF, ctDNA comprises only a small fraction of the total circulating DNA, resulting in lower sensitivity of the NGS assay [9, 62, 73, 84, 96, 97].

In the era of personalized oncology, laboratories are often asked to test minimal samples (such as the CSF) for multiple cancer biomarkers to assess patients' eligibility for targeted therapies. To this end, NGS is an attractive option, as it allows high-throughput testing in a single run saving at the same time precious diagnostic material [74, 89, 194-196]. Notably, NGS is an excellent tool to identify potential mechanisms of therapy resistance, such as the EGFR-T790M or C797S in metastatic NSCLC, in addition to concurrent alterations associated with shorter survival [197, 198], or high TMB, which is known to be predictive of response to immune checkpoint inhibitors [62]. Although existing evidence seems promising, this is mostly derived from small and retrospective studies of low statistical power (similar to 
infectious diseases). Concerning future directions, relevant NGS oncology assays should ideally be designed specifically for CSF and validated at both pre-analytical and analytical levels [9]. In addition, as most published studies describing CSF-based molecular analysis have tested ctDNA (Table 2), it would be interesting to see more studies researching DNA methylation, miRNAs [111], or exosomes. Research directed on the molecular subtypes of diverse primary or metastatic cancers such as glioblastoma [199] or breast cancer [200] could potentially improve the clinical management and patient outcomes.

As far as neuroimmunological and neurodegenerative diseases are concerned, NGS in the CSF is still in an early stage. CSF-based, single-cell NGS at genomic and transcriptomic levels has added valuable mechanistic insight for the understanding and the diagnosis of MS [201]. Compartmentalization between blood and CSF and maturation of B and T cells have extensively been studied in MS, while NGS in the CSF has offered significant help for our understanding about the development and the progression of this disease $[145,153,154,157]$. During the past two decades there was a boom in the use of genomics and transcriptomics for the study of neurodegenerative diseases [202]. However, a limited number of studies has been performed so far with NGS in the CSF of patients with $\mathrm{AD}, \mathrm{PD}$, and ALS, evaluating the potential role of miRNAs as biomarkers for disease progression. Despite their promising results, use of miRNAs as a routine examination in the CSF is still impractical, not only due to the cost but also their still undetermined significance [186, 187, 189, 191]. Moreover, studies that include other common neurodegenerative diseases, such as Frontotemporal and Lewy body dementias, are still lacking. Hence, further investigation is needed towards a wider spectrum of neurodegenerative diseases sorting out their most significant and common findings.

In conclusion, clinical application of NGS in the CSF of patients with CNS diseases can help physicians make accurate diagnoses, thus planning treatments effectively and reducing adverse effects and mortality rates. Metagenomic NGS has shown improved sensitivity-compared to traditional microbiological methods-to detect bacterial, viral, parasitic, and fungal infections, while overall diagnostic performance could be maximized when all modalities were applied. In patients with primary CNS cancers, NGS findings in the CSF were largely concordant with the molecular signatures derived from tissue-based molecular analysis, showing the potential to supplement and even replace tissuebased molecular profiling in the right clinical context, while additional mutations were detected in the CSF in some studies, reflecting intratumoral heterogeneity. In patients with metastatic CNS cancers, NGS could facilitate diagnosis and classification, prognosis, therapy selection, and follow-up, exhibiting higher sensitivity than neuroimaging, cytology, or plasma molecular analysis. Although most evidence has derived from studies dealing with infectious or neoplastic CNS disorders, NGS has shown potential to help diagnosing or understanding the pathogenesis of MS and neurodegenerative diseases, such as $\mathrm{AD}, \mathrm{PD}$, and ALS. However, as all aforementioned applications are still in an early phase, validation of NGS for each clinical scenario at both preanalytical and analytical levels is vital. Lastly, as most evidence stems from small and retrospective series, studies in the form of randomized controlled trials would be of paramount importance to establish clinical validity and utility.

\section{Declarations}

Funding No funding was received to assist with the preparation of this article.

Conflict of interest The authors disclose no conflicts of interest.

Ethics approval Not applicable.

Consent Not applicable.

Data availability statement Not applicable.

Author contributions KIT, HS, AG, HSR, CG and IPN analyzed the bibliography, prepared all tables and wrote the manuscript. IPN designed the manuscript, prepared all figures and supervised the preparation of the manuscript.

\section{References}

1. Barshes N, Demopoulos A, Engelhard HH. Anatomy and physiology of the leptomeninges and CSF space. Cancer Treat Res. 2005;125:1-16. https://doi.org/10.1007/0-387-24199-x_1.

2. Wright BLC, Lai JTF, Sinclair AJ. Cerebrospinal fluid and lumbar puncture: a practical review. J Neurol. 2012;259(8):1530-45. https://doi.org/10.1007/s00415-012-6413-x.

3. Doherty CM, Forbes RB. Diagnostic lumbar puncture. Ulster Med J. 2014;83(2):93-102.

4. Polage CR, Cohen SH. State-of-the-art microbiologic testing for community-acquired meningitis and encephalitis. J Clin Microbiol. 2016;54(5):1197-202. https://doi.org/10.1128/JCM.00289 $-16$.

5. Salzberg SL, Breitwieser FP, Kumar A, Hao H, Burger P, Rodriguez FJ, et al. Next-generation sequencing in neuropathologic diagnosis of infections of the nervous system. Neurol Neuroimmunol Neuroinflamm. 2016;3(4):e251. https://doi.org/10.1212/ NXI.0000000000000251.

6. Chamberlain MC, Glantz M, Groves MD, Wilson WH. Diagnostic tools for neoplastic meningitis: detecting disease, identifying patient risk, and determining benefit of treatment. Semin Oncol. 2009;36(4 Suppl 2):S35-45. https://doi.org/10.1053/j.seminoncol 2009.05.005.

7. Weston CL, Glantz MJ, Connor JR. Detection of cancer cells in the cerebrospinal fluid: current methods and future directions. Fluids Barr CNS. 2011;8(1):14. https://doi. org/10.1186/2045-8118-8-14. 
8. Bernitsas E, Khan O, Razmjou S, Tselis A, Bao F, Caon C, et al. Cerebrospinal fluid humoral immunity in the differential diagnosis of multiple sclerosis. PLoS ONE. 2017;12(7):e0181431. https://doi.org/10.1371/journal.pone.0181431.

9. McEwen AE, Leary SES, Lockwood CM. Beyond the blood: CSF-derived cfDNA for diagnosis and characterization of CNS tumors. Front Cell Dev Biol. 2020;8:45. https://doi.org/10.3389/ fcell.2020.00045.

10. Kulski JK. Next-generation sequencing - an overview of the history, tools, and "Omic" applications. Next generation sequencing advances, applications and challenges. 2016. https://doi. org/10.5772/61964.

11. Horak P, Fröhling S, Glimm H. Integrating next-generation sequencing into clinical oncology: strategies, promises and pitfalls. ESMO Open. 2016;1(5):e000094. https://doi.org/10.1136/ esmoopen-2016-000094.

12. Gu W, Miller S, Chiu CY. Clinical metagenomic next-generation sequencing for pathogen detection. Annu Rev Pathol. 2019;14:319-38. https://doi.org/10.1146/annurev-pathmechdi s-012418-012751.

13. Angelucci F, Cechova K, Valis M, Kuca K, Zhang B, Hort J. MicroRNAs in Alzheimer's disease: diagnostic markers or therapeutic agents? Front Pharmacol. 2019;10:665. https://doi. org/10.3389/fphar.2019.00665.

14. Liu J, Jennings SF, Tong W, Hong H. Next generation sequencing for profiling expression of miRNAs: technical progress and applications in drug development. J Biomed Sci Eng. 2011;4(10):66676. https://doi.org/10.4236/jbise.2011.410083

15. Peng Y, Croce CM. The role of MicroRNAs in human cancer. Signal Transduct Target Ther. 2016;1:15004. https://doi. org/10.1038/sigtrans.2015.4.

16. Miller S, Naccache SN, Samayoa E, Messacar K, Arevalo S, Federman $\mathrm{S}$, et al. Laboratory validation of a clinical metagenomic sequencing assay for pathogen detection in cerebrospinal fluid. Genome Res. 2019;29(5):831-42. https://doi.org/10.1101/ gr.238170.118.

17. Zimmer AJ, Burke VE, Bloch KC. Central nervous system infections. Microbiol Spectrosc. 2016. https://doi.org/10.1128/micro biolspec.DMIH2-0012-2015.

18. Hong NTT, Nghia HDT, Thanh TT, Lan NPH, Ny NTH, Ngoc $\mathrm{NM}$, et al. Cerebrospinal fluid MinION sequencing of $16 \mathrm{~S}$ rRNA gene for rapid and accurate diagnosis of bacterial meningitis. J Infect. 2020;80(4):469-96. https://doi.org/10.1016/j. jinf.2019.12.011.

19. Hu Z, Weng X, Xu C, Lin Y, Cheng C, Wei H, et al. Metagenomic next-generation sequencing as a diagnostic tool for toxoplasmic encephalitis. Ann Clin Microbiol Antimicrob. 2018;17(1):45. https://doi.org/10.1186/s12941-018-0298-1.

20. Perlejewski K, Popiel M, Laskus T, Nakamura S, Motooka D, Stokowy T, et al. Next-generation sequencing (NGS) in the identification of encephalitis-causing viruses: unexpected detection of human herpesvirus 1 while searching for RNA pathogens. J Virol Methods. 2015;226:1-6. https://doi.org/10.1016/j.jviro met.2015.09.010.

21. Huttunen $P$, Lappalainen M, Salo E, Lonnqvist T, Jokela P, Hyypia $T$, et al. Differential diagnosis of acute central nervous system infections in children using modern microbiological methods. Acta Paediatr. 2009;98(8):1300-6. https://doi.org/10 $.1111 /$ j.1651-2227.2009.01336.x.

22. Brown JR, Bharucha T, Breuer J. Encephalitis diagnosis using metagenomics: application of next generation sequencing for undiagnosed cases. J Infect. 2018;76(3):225-40. https://doi. org/10.1016/j.jinf.2017.12.014.

23. Chiu CY, Miller SA. Clinical metagenomics. Nat Rev Genet. 2019;20(6):341-55. https://doi.org/10.1038/s41576-019-0113-7.
24. Edridge AWD, Deijs M, van Zeggeren IE, Kinsella CM, Jebbink MF, Bakker M et al. Viral metagenomics on cerebrospinal fluid. Genes (Basel). 2019. https://doi.org/10.3390/genes10050332.

25. Kawada J, Okuno Y, Torii Y, Okada R, Hayano S, Ando S, et al. Identification of viruses in cases of pediatric acute encephalitis and encephalopathy using next-generation sequencing. Sci Rep. 2016;6:33452. https://doi.org/10.1038/srep33452.

26. Yao M, Zhou J, Zhu Y, Zhang Y, Lv X, Sun R, et al. Detection of Listeria monocytogenes in CSF from three patients with meningoencephalitis by next-generation sequencing. J Clin Neurol. 2016;12(4):446-51. https://doi.org/10.3988/jen.2016.12.4.446.

27. Achrol AS, Rennert RC, Anders C, Soffietti R, Ahluwalia MS, Nayak L, et al. Brain metastases. Nat Rev Dis Prim. 2019;5(1):5. https://doi.org/10.1038/s41572-018-0055-y.

28. Lavezzo E, Toppo S, Franchin E, Di Camillo B, Finotello F, Falda M, et al. Genomic comparative analysis and gene function prediction in infectious diseases: application to the investigation of a meningitis outbreak. BMC Infect Dis. 2013;13:554. https:// doi.org/10.1186/1471-2334-13-554.

29. Dulanto Chiang A, Dekker JP. From the pipeline to the bedside: advances and challenges in clinical metagenomics. J Infect Dis. 2020;221(Supplement_3):S331-40. https://doi.org/10.1093/infdi s/jiz151.

30. Eerkens JW, Nichols RV, Murray GGR, Perez K, Murga E, Kaijankoski $\mathrm{P}$, et al. A probable prehistoric case of meningococcal disease from San Francisco Bay: next generation sequencing of Neisseria meningitidis from dental calculus and osteological evidence. Int J Paleopathol. 2018;22:173-80. https://doi. org/10.1016/j.ijpp.2018.05.001.

31. Kufner V, Plate A, Schmutz S, Braun DL, Gunthard HF, Capaul $\mathrm{R}$, et al. Two years of viral metagenomics in a tertiary diagnostics unit: evaluation of the first 105 cases. Genes (Basel). 2019. https ://doi.org/10.3390/genes10090661.

32. Wilson MR, Sample HA, Zorn KC, Arevalo S, Yu G, Neuhaus $\mathrm{J}$, et al. Clinical metagenomic sequencing for diagnosis of meningitis and encephalitis. N Engl J Med. 2019;380(24):2327-40. https://doi.org/10.1056/NEJMoa1803396.

33. Fan S, Ren H, Wei Y, Mao C, Ma Z, Zhang L, et al. Next-generation sequencing of the cerebrospinal fluid in the diagnosis of neurobrucellosis. Int J Infect Dis. 2018;67:20-4. https://doi. org/10.1016/j.ijid.2017.11.028.

34. Ji XC, Zhou LF, Li CY, Shi YJ, Wu ML, Zhang Y, et al. Reduction of human DNA contamination in clinical cerebrospinal fluid specimens improves the sensitivity of metagenomic next-generation sequencing. J Mol Neurosci. 2020;70(5):659-66. https://doi. org/10.1007/s12031-019-01472-z.

35. Dando SJ, Mackay-Sim A, Norton R, Currie BJ, St John JA, Ekberg JA, et al. Pathogens penetrating the central nervous system: infection pathways and the cellular and molecular mechanisms of invasion. Clin Microbiol Rev. 2014;27(4):691-726. https://doi.org/10.1128/CMR.00118-13.

36. Brouwer MC, Thwaites GE, Tunkel AR, van de Beek D. Dilemmas in the diagnosis of acute community-acquired bacterial meningitis. Lancet. 2012;380(9854):1684-92. https://doi. org/10.1016/S0140-6736(12)61185-4.

37. Nakagawa S, Inoue S, Kryukov K, Yamagishi J, Ohno A, Hayashida K, et al. Rapid sequencing-based diagnosis of infectious bacterial species from meningitis patients in Zambia. Clin Transl Immunol. 2019;8(11):e01087. https://doi.org/10.1002/ cti2.1087.

38. Ortiz-Alcantara JM, Segura-Candelas JM, Garces-Ayala F, Gonzalez-Duran E, Rodriguez-Castillo A, Alcantara-Perez P, et al. Fatal Psychrobacter sp. infection in a pediatric patient with meningitis identified by metagenomic next-generation sequencing in cerebrospinal fluid. Arch Microbiol. 2016;198(2):129-35. https ://doi.org/10.1007/s00203-015-1168-2. 
39. Zhang XX, Guo LY, Liu LL, Shen A, Feng WY, Huang WH, et al. The diagnostic value of metagenomic next-generation sequencing for identifying Streptococcus pneumoniae in paediatric bacterial meningitis. BMC Infect Dis. 2019;19(1):495. https ://doi.org/10.1186/s12879-019-4132-y.

40. Ho Dang Trung N, Le Thi Phuong T, Wolbers M, Nguyen Van Minh H, Nguyen Thanh V, Van MP et al. Aetiologies of central nervous system infection in Viet Nam: a prospective provincial hospital-based descriptive surveillance study. PLoS One. 2012;7(5):e37825. https://doi.org/10.1371/journal.pone.00378 25 .

41. Retchless AC, Fox LM, Maiden MCJ, Smith V, Harrison LH, Glennie L, et al. Toward a global genomic epidemiology of meningococcal disease. J Infect Dis. 2019;220(220 Suppl 4):S266-73. https://doi.org/10.1093/infdis/jiz279.

42. Fan Y, Zhu X, Xu Y, Lu X, Xu Y, Wang M, et al. Cell-cycle and DNA-damage response pathway is involved in leptomeningeal metastasis of non-small cell lung cancer. Clin Cancer Res. 2018;24(1):209-16. https://doi.org/10.1158/1078-0432. CCR-17-1582.

43. Yan L, Sun W, Lu Z, Fan L. Metagenomic next-generation sequencing (mNGS) in cerebrospinal fluid for rapid diagnosis of Tuberculosis meningitis in HIV-negative population. Int J Infect Dis. 2020;96:270-5. https://doi.org/10.1016/j.ijid.2020.04.048.

44. Wang S, Chen Y, Wang D, Wu Y, Zhao D, Zhang J, et al. The Feasibility of metagenomic next-generation sequencing to identify pathogens causing Tuberculous meningitis in cerebrospinal fluid. Front Microbiol. 2019;10:1993. https://doi.org/10.3389/ fmicb.2019.01993.

45. Wang Q, Wang K, Zhang Y, Lu C, Yan Y, Huang X, et al. Neonatal Ureaplasma parvum meningitis: a case report and literature review. Transl Pediatr. 2020;9(2):174-9. https://doi.org/10.21037 /tp.2020.02.04.

46. Bukowska-Osko I, Perlejewski K, Nakamura S, Motooka D, Stokowy T, Kosinska J, et al. Sensitivity of next-generation sequencing metagenomic analysis for detection of RNA and DNA viruses in cerebrospinal fluid: the confounding effect of background contamination. Adv Exp Med Biol. 2016. https:// doi.org/10.1007/5584_2016_42.

47. Kiselev D, Matsvay A, Abramov I, Dedkov V, Shipulin G, Khafizov K. Current trends in diagnostics of viral infections of unknown etiology. Viruses. 2020. https://doi.org/10.3390/v1202 0211.

48. Saha S, Ramesh A, Kalantar K, Malaker R, Hasanuzzaman M, Khan LM, et al. Unbiased metagenomic sequencing for pediatric meningitis in Bangladesh reveals neuroinvasive chikungunya virus outbreak and other unrealized pathogens. mBio. 2019. https ://doi.org/10.1128/mBio.02877-19.

49. Wang Q, Li J, Ji J, Yang L, Chen L, Zhou R, et al. A case of Naegleria fowleri related primary amoebic meningoencephalitis in China diagnosed by next-generation sequencing. BMC Infect Dis. 2018;18(1):349. https://doi.org/10.1186/s12879-018-3261-z.

50. Fan S, Qiao X, Liu L, Wu H, Zhou J, Sun R, et al. Next-generation sequencing of cerebrospinal fluid for the diagnosis of neurocysticercosis. Front Neurol. 2018;9:471. https://doi.org/10.3389/ fneur.2018.00471.

51. Fei X, Li C, Zhang Y, Zhang H, Liu X, Ji X, et al. Next-generation sequencing of cerebrospinal fluid for the diagnosis of neurocysticercosis. Clin Neurol Neurosurg. 2020;193:105752. https://doi.org/10.1016/j.clineuro.2020.105752.

52. Liu P, Weng X, Zhou J, Xu X, He F, Du Y, et al. Next generation sequencing based pathogen analysis in a patient with neurocysticercosis: a case report. BMC Infect Dis. 2018;18(1):113. https ://doi.org/10.1186/s12879-018-3015-y.

53. Zou Y, Guan H, Wu H, Bu H, Yan L, Zhu Y, et al. Angiostrongyliasis detected by next-generation sequencing in a
ELISA-negative eosinophilic meningitis: a case report. Int J Infect Dis. 2020;97:177-9. https://doi.org/10.1016/j. ijid.2020.05.108.

54. Xie M, Zhou Z, Guo S, Li Z, Zhao H, Deng J. Next-generation sequencing specifies Angiostrongylus eosinophilic meningoencephalitis in infants: two case reports. Medicine (Baltimore). 2019;98(35):e16985. https://doi.org/10.1097/MD.0000000000 016985.

55. Skipper C, Abassi M, Boulware DR. Diagnosis and management of central nervous system cryptococcal infections in HIVinfected adults. J Fungi (Basel). 2019. https://doi.org/10.3390/ jof5030065.

56. Spadari CC, Wirth F, Lopes LB, Ishida K. New approaches for cryptococcosis treatment. Microorganisms. 2020. https://doi. org/10.3390/microorganisms8040613.

57. Xing XW, Zhang JT, Ma YB, Zheng N, Yang F, Yu SY. Apparent performance of metagenomic next-generation sequencing in the diagnosis of cryptococcal meningitis: a descriptive study. J Med Microbiol. 2019;68(8):1204-10. https://doi.org/10.1099/ jmm.0.000994.

58. Ramachandran PS, Cresswell FV, Meya DB, Langelier C, Crawford ED, DeRisi JL, et al. Detection of cryptococcus DNA by metagenomic next-generation sequencing in symptomatic cryptococcal antigenemia. Clin Infect Dis. 2019;68(11):1978-9. https ://doi.org/10.1093/cid/ciy1024.

59. Wilson MR, O'Donovan BD, Gelfand JM, Sample HA, Chow FC, Betjemann JP, et al. Chronic meningitis investigated via metagenomic next-generation sequencing. JAMA Neurol. 2018;75(8):947-55. https://doi.org/10.1001/jamaneurol .2018 .0463 .

60. Louis DN, Perry A, Reifenberger G, von Deimling A, FigarellaBranger D, Cavenee WK, et al. The 2016 World Health Organization classification of tumors of the central nervous system: a summary. Acta Neuropathol. 2016;131(6):803-20. https://doi. org/10.1007/s00401-016-1545-1.

61. Preusser M, Winkler F, Valiente M, Manegold C, Moyal E, Widhalm G, et al. Recent advances in the biology and treatment of brain metastases of non-small cell lung cancer: summary of a multidisciplinary roundtable discussion. ESMO Open. 2018;3(1):e000262. https://doi.org/10.1136/esmoopen-2017000262 .

62. von Baumgarten L, Kumbrink J, Jung A, Reischer A, Flach M, Liebmann S, et al. Therapeutic management of neuro-oncologic patients-potential relevance of CSF liquid biopsy. Theranostics. 2020;10(2):856-66. https://doi.org/10.7150/thno.36884.

63. Han $\mathrm{CH}$, Brastianos PK. Genetic characterization of brain metastases in the era of targeted therapy. Front Oncol. 2017;7:230. https://doi.org/10.3389/fonc.2017.00230.

64. Jovčevska I. Sequencing the next generation of glioblastomas. Crit Rev Clin Lab Sci. 2018;55(4):264-82. https://doi. org/10.1080/10408363.2018.1462759.

65. Vanderlaan PA, Yamaguchi N, Folch E, Boucher DH, Kent MS, Gangadharan SP, et al. Success and failure rates of tumor genotyping techniques in routine pathological samples with nonsmall-cell lung cancer. Lung Cancer. 2014;84(1):39-44. https:// doi.org/10.1016/j.lungcan.2014.01.013.

66. Qazi MA, Vora P, Venugopal C, Sidhu SS, Moffat J, Swanton $\mathrm{C}$, et al. Intratumoral heterogeneity: pathways to treatment resistance and relapse in human glioblastoma. Ann Oncol. 2017;28(7):1448-56. https://doi.org/10.1093/annonc/mdx169.

67. Sottoriva A, Spiteri I, Piccirillo SGM, Touloumis A, Collins VP, Marioni JC, et al. Intratumor heterogeneity in human glioblastoma reflects cancer evolutionary dynamics. Proc Natl Acad Sci USA. 2013;110(10):4009-14. https://doi.org/10.1073/ pnas. 1219747110. 
68. Ponti G, Manfredini M, Tomasi A. Non-blood sources of cellfree DNA for cancer molecular profiling in clinical pathology and oncology. Crit Rev Oncol Hematol. 2019;141:36-42. https ://doi.org/10.1016/j.critrevonc.2019.06.005.

69. Poulet G, Massias J, Taly V. Liquid biopsy: general concepts. Acta Cytol. 2019;63(6):449-55. https://doi.org/10.1159/00049 9337.

70. Grigoriadou G, Esagian SM, Ryu HS, Nikas IP. Molecular profiling of malignant pleural effusions with next generation sequencing (NGS): evidence that supports its role in cancer management. J Pers Med. 2020. https://doi.org/10.3390/jpm10040206.

71. Esagian SM, Grigoriadou GI, Nikas IP, Boikou V, Sadow PM, Won J-K, et al. Comparison of liquid-based to tissue-based biopsy analysis by targeted next generation sequencing in advanced non-small cell lung cancer: a comprehensive systematic review. J Cancer Res Clin Oncol. 2020;146(8):2051-66. https://doi.org/10.1007/s00432-020-03267-x.

72. Merker JD, Oxnard GR, Compton C, Diehn M, Hurley P, Lazar AJ, et al. Circulating tumor DNA analysis in patients with cancer: American Society of Clinical Oncology and College of American Pathologists Joint Review. J Clin Oncol. 2018;36(16):1631-41. https://doi.org/10.1200/JCO.2017.76.8671.

73. Stewart CM, Kothari PD, Mouliere F, Mair R, Somnay S, Benayed R, et al. The value of cell-free DNA for molecular pathology. J Pathol. 2018;244(5):616-27. https://doi. org/10.1002/path.5048.

74. Kamps R, Brandão RD, van den Bosch BJ, Paulussen ADC, Xanthoulea S, Blok MJ, et al. Next-generation sequencing in oncology: genetic diagnosis, risk prediction and cancer classification. Int J Mol Sci. 2017. https://doi.org/10.3390/ijms18020308.

75. Bray F, Ferlay J, Soerjomataram I, Siegel RL, Torre LA, Jemal A. Global cancer statistics 2018: GLOBOCAN estimates of incidence and mortality worldwide for 36 cancers in 185 countries. CA Cancer J Clin. 2018;68(6):394-424. https://doi.org/10.3322/ caac. 21492.

76. Udaka YT, Packer RJ. Pediatric brain tumors. Neurol Clin. 2018;36(3):533-56. https://doi.org/10.1016/j.ncl.2018.04.009.

77. Kristensen BW, Priesterbach-Ackley LP, Petersen JK, Wesseling P. Molecular pathology of tumors of the central nervous system. Ann Oncol. 2019;30(8):1265-78. https://doi.org/10.1093/annon c/mdz164

78. Hegi ME, Diserens A-C, Gorlia T, Hamou M-F, de Tribolet N, Weller M, et al. MGMT gene silencing and benefit from temozolomide in glioblastoma. N Engl J Med. 2005;352(10):997-1003. https://doi.org/10.1056/NEJMoa043331.

79. Juratli TA, Stasik S, Zolal A, Schuster C, Richter S, Daubner $\mathrm{D}$, et al. TERT promoter mutation detection in cell-free tumorderived DNA in patients with IDH wild-type glioblastomas: a pilot prospective study. Clin Cancer Res. 2018;24(21):5282-91. https://doi.org/10.1158/1078-0432.CCR-17-3717.

80. Johnson BE, Mazor T, Hong C, Barnes M, Aihara K, McLean CY, et al. Mutational analysis reveals the origin and therapy-driven evolution of recurrent glioma. Science. 2014;343(6167):189-93. https://doi.org/10.1126/science.1239947.

81. Martínez-Ricarte F, Mayor R, Martínez-Sáez E, Rubio-Pérez C, Pineda E, Cordero E, et al. Molecular diagnosis of diffuse gliomas through sequencing of cell-free circulating tumor DNA from cerebrospinal fluid. Clin Cancer Res. 2018;24(12):2812-9. https ://doi.org/10.1158/1078-0432.CCR-17-3800.

82. Zhao Z, Zhang C, Li M, Shen Y, Feng S, Liu J, et al. Applications of cerebrospinal fluid circulating tumor DNA in the diagnosis of gliomas. Jpn J Clin Oncol. 2020;50(3):325-32. https://doi. org/10.1093/jjco/hyz156.

83. Li J-H, He Z-Q, Lin F-H, Chen Z-H, Yang S-Y, Duan H, et al. Assessment of ctDNA in CSF may be a more rapid means of assessing surgical outcomes than plasma ctDNA in glioblastoma.
Mol Cell Probes. 2019;46:101411. https://doi.org/10.1016/j. mcp.2019.06.001.

84. Miller AM, Shah RH, Pentsova EI, Pourmaleki M, Briggs S, Distefano N, et al. Tracking tumour evolution in glioma through liquid biopsies of cerebrospinal fluid. Nature. 2019;565(7741):6548. https://doi.org/10.1038/s41586-019-0882-3.

85. Duan H, Hu J-L, Chen Z-H, Li J-H, He Z-Q, Wang Z-N, et al. Assessment of circulating tumor DNA in cerebrospinal fluid by whole exome sequencing to detect genomic alterations of glioblastoma. Chin Med J. 2020. https://doi.org/10.1097/CM9.00000 00000000843.

86. Pan W, Gu W, Nagpal S, Gephart MH, Quake SR. Brain tumor mutations detected in cerebral spinal fluid. Clin Chem. 2015;61(3):514-22. https://doi.org/10.1373/clinc hem.2014.235457.

87. Mouliere F, Mair R, Chandrananda D, Marass F, Smith CG, Su J, et al. Detection of cell-free DNA fragmentation and copy number alterations in cerebrospinal fluid from glioma patients. EMBO Mol Med. 2018. https://doi.org/10.15252/emmm.201809323.

88. Wang Y, Springer S, Zhang M, McMahon KW, Kinde I, Dobbyn L, et al. Detection of tumor-derived DNA in cerebrospinal fluid of patients with primary tumors of the brain and spinal cord. Proc Natl Acad Sci USA. 2015;112(31):9704-9. https:// doi.org/10.1073/pnas.1511694112.

89. Kalemkerian GP, Narula N, Kennedy EB, Biermann WA, Donington J, Leighl NB, et al. Molecular testing guideline for the selection of patients with lung cancer for treatment with targeted tyrosine kinase inhibitors: American Society of Clinical Oncology Endorsement of the College of American Pathologists/International Association for the Study of Lung Cancer/Association for Molecular Pathology Clinical Practice Guideline Update. J Clin Oncol. 2018;36(9):911-9.

90. Lindeman NI, Cagle PT, Aisner DL, Arcila ME, Beasley MB, Bernicker EH, et al. Updated molecular testing guideline for the selection of lung cancer patients for treatment with targeted tyrosine kinase inhibitors: guideline from the College of American Pathologists, the International Association for the Study of Lung Cancer, and the Association for Molecular Pathology. Arch Pathol Lab Med. 2018;142(3):321-46. https://doi.org/10.5858/ arpa.2017-0388-CP.

91. Soffietti R, Abacioglu U, Baumert B, Combs SE, Kinhult S, Kros $\mathrm{JM}$, et al. Diagnosis and treatment of brain metastases from solid tumors: guidelines from the European Association of NeuroOncology (EANO). Neuro Oncol. 2017;19(2):162-74. https:// doi.org/10.1093/neuonc/now241.

92. Nikas I, Ryu HS, Theocharis S. Viewing the Eph receptors with a focus on breast cancer heterogeneity. Cancer Lett. 2018;434:160 71. https://doi.org/10.1016/j.canlet.2018.07.030.

93. Bae YS, Cheong J-W, Chang WS, Kim S, Oh EJ, Kim SH. Diagnostic accuracy of cerebrospinal fluid (CSF) cytology in metastatic tumors: an analysis of consecutive CSF samples. Korean J Pathol. 2013;47(6):563-8. https://doi.org/10.4132/KoreanJPat hol.2013.47.6.563.

94. Pope WB. Brain metastases: neuroimaging. Handb Clin Neurol. 2018;149:89-112. https://doi.org/10.1016/B978-0-12-81116 1-1.00007-4.

95. Ballester LY, Glitza Oliva IC, Douse DY, Chen MM, Lan C, Haydu LE, et al. Evaluating circulating tumor DNA from the cerebrospinal fluid of patients with melanoma and leptomeningeal disease. J Neuropathol Exp Neurol. 2018;77(7):628-35. https:// doi.org/10.1093/jnen/nly046.

96. Pentsova EI, Shah RH, Tang J, Boire A, You D, Briggs $\mathrm{S}$, et al. Evaluating cancer of the central nervous system through next-generation sequencing of cerebrospinal fluid. J Clin Oncol. 2016;34(20):2404-15. https://doi.org/10.1200/ JCO.2016.66.6487. 
97. Villatoro S, Mayo-de-Las-Casas C, Jordana-Ariza N, ViteriRamírez S, Garzón-Ibañez M, Moya-Horno I, et al. Prospective detection of mutations in cerebrospinal fluid, pleural effusion, and ascites of advanced cancer patients to guide treatment decisions. Mol Oncol. 2019;13(12):2633-45. https://doi. org/10.1002/1878-0261.12574.

98. Zhao Y, He J-Y, Zou Y-L, Guo X-S, Cui J-Z, Guo L, et al. Evaluating the cerebrospinal fluid ctDNA detection by next-generation sequencing in the diagnosis of meningeal Carcinomatosis. BMC Neurol. 2019;19(1):331. https://doi.org/10.1186/s1288 3-019-1554-5.

99. Ge M, Zhan Q, Zhang Z, Ji X, Zhou X, Huang R, et al. Different next-generation sequencing pipelines based detection of tumor DNA in cerebrospinal fluid of lung adenocarcinoma cancer patients with leptomeningeal metastases. BMC Cancer. 2019;19(1):143. https://doi.org/10.1186/s12885-019-5348-3.

100. Ma C, Yang X, Xing W, Yu H, Si T, Guo Z. Detection of circulating tumor DNA from non-small cell lung cancer brain metastasis in cerebrospinal fluid samples. Thorac Cancer. 2020;11(3):58893. https://doi.org/10.1111/1759-7714.13300.

101. Ma C, Zhang J, Tang D, Ye X, Li J, Mu N, et al. Tyrosine kinase inhibitors could be effective against non-small cell lung cancer brain metastases harboring uncommon EGFR mutations. Front Oncol. 2020;10:224. https://doi.org/10.3389/fonc.2020.00224.

102. Zheng M-M, Li Y-S, Jiang B-Y, Tu H-Y, Tang W-F, Yang J-J, et al. Clinical utility of cerebrospinal fluid cell-free DNA as liquid biopsy for leptomeningeal metastases in ALK-rearranged NSCLC. J Thorac Oncol. 2019;14(5):924-32. https://doi. org/10.1016/j.jtho.2019.01.007.

103. Jiang B-Y, Li Y-S, Guo W-B, Zhang X-C, Chen Z-H, Su J, et al. Detection of driver and resistance mutations in leptomeningeal metastases of NSCLC by next-generation sequencing of cerebrospinal fluid circulating tumor cells. Clin Cancer Res. 2017;23(18):5480-8. https://doi.org/10.1158/1078-0432. CCR-17-0047.

104. Li YS, Jiang BY, Yang JJ, Zhang XC, Zhang Z, Ye JY, et al. Unique genetic profiles from cerebrospinal fluid cell-free DNA in leptomeningeal metastases of EGFR-mutant non-smallcell lung cancer: a new medium of liquid biopsy. Ann Oncol. 2018;29(4):945-52. https://doi.org/10.1093/annonc/mdy009.

105. Liu J, Jin B, Su H, Qu X, Liu Y. Afatinib helped overcome subsequent resistance to osimertinib in a patient with NSCLC having leptomeningeal metastasis baring acquired EGFR L718Q mutation: a case report. BMC Cancer. 2019;19(1):702. https://doi. org/10.1186/s12885-019-5915-7.

106. Shen F-F, Guo W, Tian R-F, Guo Y, Yang Y-L, Song X. Longterm survival with targeted therapy in an advanced non-small cell lung cancer patient based on genetic profiling. Transl Lung Cancer Res. 2020;9(2):373-8. https://doi.org/10.21037/ tlcr.2020.01.21.

107. De Mattos-Arruda L, Mayor R, Ng CKY, Weigelt B, MartínezRicarte F, Torrejon D, et al. Cerebrospinal fluid-derived circulating tumour DNA better represents the genomic alterations of brain tumours than plasma. Nat Commun. 2015;6:8839. https:// doi.org/10.1038/ncomms9839.

108. Li Y, Pan W, Connolly ID, Reddy S, Nagpal S, Quake S, et al. Tumor DNA in cerebral spinal fluid reflects clinical course in a patient with melanoma leptomeningeal brain metastases. J Neurooncol. 2016;128(1):93-100. https://doi.org/10.1007/s1106 0-016-2081-5.

109. Siravegna G, Geuna E, Mussolin B, Crisafulli G, Bartolini A, Galizia D, et al. Genotyping tumour DNA in cerebrospinal fluid and plasma of a HER2-positive breast cancer patient with brain metastases. ESMO Open. 2017;2(4):e000253. https://doi. org/10.1136/esmoopen-2017-000253.
110. Song Y, Liu P, Huang Y, Guan Y, Han X, Shi Y. Osimertinib quantitative and gene variation analyses in cerebrospinal fluid and plasma of a non-small cell lung cancer patient with leptomeningeal metastases. Curr Cancer Drug Targets. 2019;19(8):66673. https://doi.org/10.2174/1568009618666181017114111.

111. Kopkova A, Sana J, Machackova T, Vecera M, Radova L, Trachtova $\mathrm{K}$, et al. Cerebrospinal fluid MicroRNA signatures as diagnostic biomarkers in brain tumors. Cancers. 2019. https:// doi.org/10.3390/cancers11101546.

112. Aldea M, Hendriks L, Mezquita L, Jovelet C, Planchard D, Auclin E, et al. Circulating tumor DNA analysis for patients with oncogene-addicted NSCLC with isolated central nervous system progression. J Thorac Oncol. 2020;15(3):383-91. https:// doi.org/10.1016/j.jtho.2019.11.024.

113. Ying S, Ke H, Ding Y, Liu Y, Tang X, Yang D, et al. Unique genomic profiles obtained from cerebrospinal fluid cell-free DNA of non-small cell lung cancer patients with leptomeningeal metastases. Cancer Biol Ther. 2019;20(4):562-70. https:// doi.org/10.1080/15384047.2018.1538614.

114. Bray NJ, O'Donovan MC. The genetics of neuropsychiatric disorders. Brain Neurosci Adv. 2019. https://doi.org/10.1177/23982 12818799271.

115. Toft M. Advances in genetic diagnosis of neurological disorders. Acta Neurol Scand Suppl. 2014;198:20-5. https://doi. org/10.1111/ane.12232.

116. van den Berg MMJ, Krauskopf J, Ramaekers JG, Kleinjans JCS, Prickaerts J, Briede JJ. Circulating microRNAs as potential biomarkers for psychiatric and neurodegenerative disorders. Prog Neurobiol. 2020;185:101732. https://doi.org/10.1016/j.pneur obio.2019.101732.

117. Han G, Sun J, Wang J, Bai Z, Song F, Lei H. Genomics in neurological disorders. Genom Proteom Bioinform. 2014;12(4):15663. https://doi.org/10.1016/j.gpb.2014.07.002.

118. Sorensen SS, Nygaard AB, Carlsen AL, Heegaard NHH, Bak M, Christensen T. Elevation of brain-enriched miRNAs in cerebrospinal fluid of patients with acute ischemic stroke. Biomark Res. 2017;5:24. https://doi.org/10.1186/s40364-017-0104-9.

119. Ghralaigh FN, Gallagher L, Lopez LM. Autism spectrum disorder genomics: the progress and potential of genomic technologies. Genomics. 2020. https://doi.org/10.1016/j.ygeno 2020.09.022.

120. Buch AM, Liston C. Dissecting diagnostic heterogeneity in depression by integrating neuroimaging and genetics. Neuropsychopharmacology. 2020. https://doi.org/10.1038/s4138 6-020-00789-3.

121. Lemvigh CK, Brouwer RM, Pantelis C, Jensen MH, Hilker RW, Legind CS, et al. Heritability of specific cognitive functions and associations with schizophrenia spectrum disorders using CANTAB: a nation-wide twin study. Psychol Med. 2020. https://doi. org/10.1017/S0033291720002858.

122. Li W, Cai X, Li HJ, Song M, Zhang CY, Yang Y, et al. Independent replications and integrative analyses confirm TRANK1 as a susceptibility gene for bipolar disorder. Neuropsychopharmacology. 2020. https://doi.org/10.1038/s41386-020-00788-4.

123. Tomasik J, Smits SL, Leweke FM, Eljasz P, Pas S, Kahn RS, et al. Virus discovery analyses on post-mortem brain tissue and cerebrospinal fluid of schizophrenia patients. Schizophr Res. 2018;197:605-6. https://doi.org/10.1016/j.schres.2018.02.012.

124. Didonna A, Oksenberg JR. The genetics of multiple sclerosis. In: Zagon IS, McLaughlin PJ, editors. Multiple sclerosis: perspectives in treatment and pathogenesis. Brisbane (AU); 2017.

125. Haines JL, Terwedow HA, Burgess K, Pericak-Vance MA, Rimmler JB, Martin ER et al. Linkage of the MHC to familial multiple sclerosis suggests genetic heterogeneity. The Multiple Sclerosis Genetics Group. Hum Mol Genet. 1998;7(8):1229-34. https://doi.org/10.1093/hmg/7.8.1229. 
126. Horton R, Wilming L, Rand V, Lovering RC, Bruford EA, Khodiyar VK, et al. Gene map of the extended human MHC. Nat Rev Genet. 2004;5(12):889-99. https://doi.org/10.1038/nrg1489.

127. Winchester R, Ebers G, Fu SM, Espinosa L, Zabriskie J, Kunkel HG. B-cell alloantigen Ag 7a in multiple sclerosis. Lancet. 1975;2(7939):814. https://doi.org/10.1016/s0140-6736(75)80033 $-\mathrm{x}$.

128. Patsopoulos NA. Genetics of multiple sclerosis: an overview and new directions. Cold Spring Harb Perspect Med. 2018. https:// doi.org/10.1101/cshperspect.a028951.

129. De Jager PL, Jia X, Wang J, de Bakker PI, Ottoboni L, Aggarwal NT, et al. Meta-analysis of genome scans and replication identify CD6, IRF8 and TNFRSF1A as new multiple sclerosis susceptibility loci. Nat Genet. 2009;41(7):776-82. https://doi. org/10.1038/ng.401.

130. Matesanz F, Gonzalez-Perez A, Lucas M, Sanna S, Gayan J, Urcelay E, et al. Genome-wide association study of multiple sclerosis confirms a novel locus at 5p13.1. PLoS One. 2012;7(5):e36140. https://doi.org/10.1371/journal.pone.00361 40.

131. Patsopoulos NA, Bayer Pharma MSGWG, Steering Committees of Studies Evaluating I-b, a CCRA, Consortium AN, GeneMsa et al. Genome-wide meta-analysis identifies novel multiple sclerosis susceptibility loci. Ann Neurol. 2011;70(6):897-912. https ://doi.org/10.1002/ana.22609.

132. Didonna A, Isobe N, Caillier SJ, Li KH, Burlingame AL, Hauser SL, et al. A non-synonymous single-nucleotide polymorphism associated with multiple sclerosis risk affects the EVI5 interactome. Hum Mol Genet. 2015;24(24):7151-8. https://doi. org $/ 10.1093 / \mathrm{hmg} / \mathrm{ddv} 412$.

133. Gregory SG, Schmidt S, Seth P, Oksenberg JR, Hart J, Prokop A, et al. Interleukin 7 receptor alpha chain (IL7R) shows allelic and functional association with multiple sclerosis. Nat Genet. 2007;39(9):1083-91. https://doi.org/10.1038/ng2103.

134. Maier LM, Lowe CE, Cooper J, Downes K, Anderson DE, Severson C, et al. IL2RA genetic heterogeneity in multiple sclerosis and type 1 diabetes susceptibility and soluble interleukin-2 receptor production. PLoS Genet. 2009;5(1):e1000322. https:// doi.org/10.1371/journal.pgen.1000322.

135. Andlauer TF, Buck D, Antony G, Bayas A, Bechmann L, Berthele A, et al. Novel multiple sclerosis susceptibility loci implicated in epigenetic regulation. Sci Adv. 2016;2(6):e1501678. https://doi. org/10.1126/sciadv.1501678.

136. Damotte V, Guillot-Noel L, Patsopoulos NA, Madireddy L, El Behi M, International Multiple Sclerosis Genetics C, et al. A gene pathway analysis highlights the role of cellular adhesion molecules in multiple sclerosis susceptibility. Genes Immun. 2014;15(2):126-32. https://doi.org/10.1038/gene.2013.70.

137. International Multiple Sclerosis Genetics C. Network-based multiple sclerosis pathway analysis with GWAS data from 15,000 cases and 30,000 controls. Am J Hum Genet. 2013;92(6):854-65. https://doi.org/10.1016/j.ajhg.2013.04.019.

138. International Multiple Sclerosis Genetics C, Beecham AH, Patsopoulos NA, Xifara DK, Davis MF, Kemppinen A, et al. Analysis of immune-related loci identifies 48 new susceptibility variants for multiple sclerosis. Nat Genet. 2013;45(11):1353-60. https:// doi.org/10.1038/ng.2770.

139. Lowes H, Pyle A, Duddy M, Hudson G. Cell-free mitochondrial DNA in progressive multiple sclerosis. Mitochondrion. 2019;46:307-12. https://doi.org/10.1016/j.mito.2018.07.008.

140. van Langelaar J, Rijvers L, Smolders J, van Luijn MM. B and $\mathrm{T}$ cells driving multiple sclerosis: identity, mechanisms and potential triggers. Front Immunol. 2020;11:760. https://doi. org/10.3389/fimmu.2020.00760.

141. von Budingen HC, Kuo TC, Sirota M, van Belle CJ, Apeltsin L, Glanville J, et al. B cell exchange across the blood-brain barrier in multiple sclerosis. J Clin Invest. 2012;122(12):4533-43. https ://doi.org/10.1172/JCI63842.

142. Planas R, Metz I, Martin R, Sospedra M. Detailed characterization of $\mathrm{T}$ cell receptor repertoires in multiple sclerosis brain lesions. Front Immunol. 2018;9:509. https://doi.org/10.3389/ fimmu.2018.00509.

143. Bankoti J, Apeltsin L, Hauser SL, Allen S, Albertolle ME, Witkowska HE, et al. In multiple sclerosis, oligoclonal bands connect to peripheral B-cell responses. Ann Neurol. 2014;75(2):266-76. https://doi.org/10.1002/ana.24088.

144. Palanichamy A, Apeltsin L, Kuo TC, Sirota M, Wang S, Pitts $\mathrm{SJ}$, et al. Immunoglobulin class-switched B cells form an active immune axis between CNS and periphery in multiple sclerosis. Sci Transl Med. 2014;6(248):248ra106. https://doi.org/10.1126/ scitranslmed.3008930.

145. Stern JN, Yaari G, Vander Heiden JA, Church G, Donahue WF, Hintzen RQ, et al. B cells populating the multiple sclerosis brain mature in the draining cervical lymph nodes. Sci Transl Med. 2014;6(248):248ra107. https://doi.org/10.1126/scitranslm ed.3008879.

146. Rounds WH, Ligocki AJ, Levin MK, Greenberg BM, Bigwood DW, Eastman EM, et al. The antibody genetics of multiple sclerosis: comparing next-generation sequencing to sanger sequencing. Front Neurol. 2014;5:166. https://doi.org/10.3389/fneur .2014.00166.

147. Rounds WH, Salinas EA, Wilks TB 2nd, Levin MK, Ligocki AJ, Ionete C, et al. MSPrecise: a molecular diagnostic test for multiple sclerosis using next generation sequencing. Gene. 2015;572(2):191-7. https://doi.org/10.1016/j.gene.2015.07.011.

148. Johansen JN, Vartdal F, Desmarais C, Tutturen AE, de Souza GA, Lossius A, et al. Intrathecal BCR transcriptome in multiple sclerosis versus other neuroinflammation: Equally diverse and compartmentalized, but more mutated, biased and overlapping with the proteome. Clin Immunol. 2015;160(2):211-25. https:// doi.org/10.1016/j.clim.2015.06.001.

149. Ostmeyer J, Christley S, Rounds WH, Toby I, Greenberg BM, Monson NL, et al. Statistical classifiers for diagnosing disease from immune repertoires: a case study using multiple sclerosis. BMC Bioinform. 2017;18(1):401. https://doi.org/10.1186/s1285 9-017-1814-6.

150. Tomescu-Baciu A, Johansen JN, Holmoy T, Greiff V, Stensland M, de Souza GA, et al. Persistence of intrathecal oligoclonal B cells and IgG in multiple sclerosis. J Neuroimmunol. 2019;333:576966. https://doi.org/10.1016/j.jneur oim.2019.576966.

151. Beltran E, Obermeier B, Moser M, Coret F, Simo-Castello M, Bosca I, et al. Intrathecal somatic hypermutation of IgM in multiple sclerosis and neuroinflammation. Brain. 2014;137(Pt 10):2703-14. https://doi.org/10.1093/brain/awu205.

152. Planas R, Metz I, Ortiz Y, Vilarrasa N, Jelcic I, Salinas-Riester G, et al. Central role of Th2/Tc2 lymphocytes in pattern II multiple sclerosis lesions. Ann Clin Transl Neurol. 2015;2(9):875-93. https://doi.org/10.1002/acn3.218.

153. Salou M, Garcia A, Michel L, Gainche-Salmon A, Loussouarn D, Nicol B, et al. Expanded CD8 T-cell sharing between periphery and CNS in multiple sclerosis. Ann Clin Transl Neurol. 2015;2(6):609-22. https://doi.org/10.1002/acn3.199.

154. Attaf M, Sewell AK. Disease etiology and diagnosis by TCR repertoire analysis goes viral. Eur J Immunol. 2016;46(11):2516-9. https://doi.org/10.1002/eji.201646649.

155. de Paula Alves Sousa A, Johnson KR, Nicholas R, Darko S, Price DA, Douek DC, et al. Intrathecal T-cell clonal expansions in patients with multiple sclerosis. Ann Clin Transl Neurol. 2016;3(6):422-33. https://doi.org/10.1002/acn3.310.

156. Lossius A, Johansen JN, Vartdal F, Robins H, Jurate Saltyte B, Holmoy T, et al. High-throughput sequencing of TCR repertoires 
in multiple sclerosis reveals intrathecal enrichment of EBV-reactive CD8+ T cells. Eur J Immunol. 2014;44(11):3439-52. https ://doi.org/10.1002/eji.201444662.

157. Nicol B, Salou M, Vogel I, Garcia A, Dugast E, Morille J, et al. An intermediate level of CD161 expression defines a novel activated, inflammatory, and pathogenic subset of CD8(+) T cells involved in multiple sclerosis. J Autoimmun. 2018;88:61-74. https://doi.org/10.1016/j.jaut.2017.10.005.

158. Gerdes LA, Held K, Beltran E, Berking C, Prinz JC, Junker A, et al. CTLA4 as immunological checkpoint in the development of multiple sclerosis. Ann Neurol. 2016;80(2):294-300. https:// doi.org/10.1002/ana.24715.

159. Harris KM, Lim N, Lindau P, Robins H, Griffith LM, Nash RA, et al. Extensive intrathecal $\mathrm{T}$ cell renewal following hematopoietic transplantation for multiple sclerosis. JCI Insight. 2020. https ://doi.org/10.1172/jci.insight.127655.

160. Schafflick D, Xu CA, Hartlehnert M, Cole M, Schulte-Mecklenbeck A, Lautwein T, et al. Integrated single cell analysis of blood and cerebrospinal fluid leukocytes in multiple sclerosis. Nat Commun. 2020;11(1):247. https://doi.org/10.1038/s4146 7-019-14118-w.

161. Ramesh A, Schubert RD, Greenfield AL, Dandekar R, Loudermilk R, Sabatino JJ Jr, et al. A pathogenic and clonally expanded B cell transcriptome in active multiple sclerosis. Proc Natl Acad Sci USA. 2020;117(37):22932-43. https://doi.org/10.1073/ pnas. 2008523117.

162. Kowarik MC, Astling D, Gasperi C, Wemlinger S, Schumann H, Dzieciatkowska M, et al. CNS Aquaporin-4-specific B cells connect with multiple B-cell compartments in neuromyelitis optica spectrum disorder. Ann Clin Transl Neurol. 2017;4(6):369-80. https://doi.org/10.1002/acn3.418.

163. Reul S, Lohmann H, Wiendl H, Duning T, Johnen A. Can cognitive assessment really discriminate early stages of Alzheimer's and behavioural variant frontotemporal dementia at initial clinical presentation? Alzheimers Res Ther. 2017;9(1):61. https://doi. org/10.1186/s13195-017-0287-1.

164. Baizabal-Carvallo JF, Jankovic J. Parkinsonism, movement disorders and genetics in frontotemporal dementia. Nat Rev Neurol. 2016;12(3):175-85. https://doi.org/10.1038/nrneurol.2016.14.

165. Coughlin D, Xie SX, Liang M, Williams A, Peterson C, Weintraub D, et al. Cognitive and pathological influences of tau pathology in Lewy body disorders. Ann Neurol. 2019;85(2):25971. https://doi.org/10.1002/ana.25392.

166. Coulthard EJ, Love S. A broader view of dementia: multiple co-pathologies are the norm. Brain. 2018;141(7):1894-7. https ://doi.org/10.1093/brain/awy153.

167. El-Nazer R, Adler CH, Beach TG, Belden CM, Artz J, Shill HA, et al. Regional neuropathology distribution and verbal fluency impairments in Parkinson's disease. Parkinsonism Relat Disord. 2019;65:73-8. https://doi.org/10.1016/j.parkreldis.2019.05.014.

168. Robinson JL, Lee EB, Xie SX, Rennert L, Suh E, Bredenberg $\mathrm{C}$, et al. Neurodegenerative disease concomitant proteinopathies are prevalent, age-related and APOE4-associated. Brain. 2018;141(7):2181-93. https://doi.org/10.1093/brain/awy146.

169. Braak H, Del Tredici K, Rub U, de Vos RA, Jansen Steur EN, Braak E. Staging of brain pathology related to sporadic Parkinson's disease. Neurobiol Aging. 2003;24(2):197-211. https://doi. org/10.1016/s0197-4580(02)00065-9.

170. DeKosky S. Early intervention is key to successful management of Alzheimer disease. Alzheimer Dis Assoc Disord. 2003;17(Suppl 4):S99-104. https://doi.org/10.1097/00002093200307004-00004.

171. Chong MS, Sahadevan S. Preclinical Alzheimer's disease: diagnosis and prediction of progression. Lancet Neurol. 2005;4(9):576-9. https://doi.org/10.1016/S1474-4422(05)70168 $-\mathrm{X}$
172. Yiannopoulou KG, Papageorgiou SG. Current and future treatments in Alzheimer disease: an update. J Cent Nerv Syst Dis. 2020;12:1179573520907397. https://doi.org/10.1177/11795 73520907397.

173. Kaneko Y, Hirao K, Serisawa S, Kanetaka H, Shimizu S, Hirai H, et al. Association between clinical symptoms and post-mortem neuropathology in dementia with Lewy bodies. Geriatr Gerontol Int. 2020;20(3):261-2. https://doi.org/10.1111/ggi.13853.

174. Sancesario GM, Bernardini S. Alzheimer's disease in the omics era. Clin Biochem. 2018;59:9-16. https://doi.org/10.1016/j.clinb iochem.2018.06.011.

175. Genin E, Hannequin D, Wallon D, Sleegers K, Hiltunen M, Combarros O, et al. APOE and Alzheimer disease: a major gene with semi-dominant inheritance. Mol Psychiatry. 2011;16(9):903-7. https://doi.org/10.1038/mp.2011.52.

176. McKhann GM, Knopman DS, Chertkow H, Hyman BT, Jack $\mathrm{CR}$ Jr, Kawas $\mathrm{CH}$, et al. The diagnosis of dementia due to Alzheimer's disease: recommendations from the National Institute on Aging-Alzheimer's Association workgroups on diagnostic guidelines for Alzheimer's disease. Alzheimers Dement. 2011;7(3):263-9. https://doi.org/10.1016/j.jalz.2011.03.005.

177. Selkoe DJ, Hardy J. The amyloid hypothesis of Alzheimer's disease at 25 years. EMBO Mol Med. 2016;8(6):595-608. https:// doi.org/10.15252/emmm.201606210.

178. Khan TK, Alkon DL. Early diagnostic accuracy and pathophysiologic relevance of an autopsy-confirmed Alzheimer's disease peripheral biomarker. Neurobiol Aging. 2010;31(6):889-900. https://doi.org/10.1016/j.neurobiolaging.2008.07.010.

179. Pratico D. Oxidative stress hypothesis in Alzheimer's disease: a reappraisal. Trends Pharmacol Sci. 2008;29(12):609-15. https:// doi.org/10.1016/j.tips.2008.09.001.

180. Shinohara M, Sato N. Bidirectional interactions between diabetes and Alzheimer's disease. Neurochem Int. 2017;108:296-302. https://doi.org/10.1016/j.neuint.2017.04.020.

181. Whittington RA, Planel E, Terrando N. Impaired resolution of inflammation in Alzheimer's disease: a review. Front Immunol. 2017;8:1464. https://doi.org/10.3389/fimmu.2017.01464.

182. Alexandrov PN, Dua P, Hill JM, Bhattacharjee S, Zhao Y, Lukiw WJ. microRNA (miRNA) speciation in Alzheimer's disease (AD) cerebrospinal fluid (CSF) and extracellular fluid (ECF). Int J Biochem Mol Biol. 2012;3(4):365-73.

183. Sala Frigerio C, Lau P, Salta E, Tournoy J, Bossers K, Vandenberghe R, et al. Reduced expression of hsa-miR-27a-3p in CSF of patients with Alzheimer disease. Neurology. 2013;81(24):21036. https://doi.org/10.1212/01.wnl.0000437306.37850.22.

184. Sanchez-Mut JV, Graff J. Epigenetic alterations in Alzheimer's disease. Front Behav Neurosci. 2015;9:347. https://doi. org/10.3389/fnbeh.2015.00347.

185. McKeever PM, Schneider R, Taghdiri F, Weichert A, Multani N, Brown RA, et al. MicroRNA expression levels are altered in the cerebrospinal fluid of patients with young-onset Alzheimer's disease. Mol Neurobiol. 2018;55(12):8826-41. https://doi. org/10.1007/s12035-018-1032-x.

186. Jain G, Stuendl A, Rao P, Berulava T, Pena Centeno T, Kaurani $\mathrm{L}$, et al. A combined miRNA-piRNA signature to detect Alzheimer's disease. Transl Psychiatry. 2019;9(1):250. https://doi. org/10.1038/s41398-019-0579-2.

187. Burgos K, Malenica I, Metpally R, Courtright A, Rakela B, Beach T, et al. Profiles of extracellular miRNA in cerebrospinal fluid and serum from patients with Alzheimer's and Parkinson's diseases correlate with disease status and features of pathology. PLoS ONE. 2014;9(5):e94839. https://doi.org/10.1371/journ al.pone.0094839.

188. Kalia LV, Lang AE. Parkinson's disease. Lancet. 2015;386(9996):896-912. https://doi.org/10.1016/S0140 $-6736(14) 61393-3$ 
189. Hossein-Nezhad A, Fatemi RP, Ahmad R, Peskind ER, Zabetian $\mathrm{CP}, \mathrm{Hu} \mathrm{SC}$, et al. Transcriptomic profiling of extracellular RNAs present in cerebrospinal fluid identifies differentially expressed transcripts in Parkinson's disease. J Parkinsons Dis. 2016;6(1):109-17. https://doi.org/10.3233/JPD-150737.

190. Al-Chalabi A, Hardiman O, Kiernan MC, Chio A, Rix-Brooks B, van den Berg LH. Amyotrophic lateral sclerosis: moving towards a new classification system. Lancet Neurol. 2016;15(11):118294. https://doi.org/10.1016/S1474-4422(16)30199-5.

191. Otake K, Kamiguchi H, Hirozane Y. Identification of biomarkers for amyotrophic lateral sclerosis by comprehensive analysis of exosomal mRNAs in human cerebrospinal fluid. BMC Med Genom. 2019;12(1):7. https://doi.org/10.1186/s1292 0-019-0473-z.

192. Nikas I, Hapfelmeier A, Mollenhauer M, Angermeier D, Bettstetter M, Gotz R, et al. Integrated morphologic and molecular analysis of Trichomonas vaginalis, Mycoplasma hominis, and human papillomavirus using cytologic smear preparations. Parasitol Res. 2018;117(5):1443-51. https://doi.org/10.1007/s0043 6-018-5829-3.

193. Vandenberghe N, Leveque N, Corcia P, Brunaud-Danel V, SalortCampana E, Besson G, et al. Cerebrospinal fluid detection of enterovirus genome in ALS: a study of 242 patients and 354 controls. Amyotroph Lateral Scler. 2010;11(3):277-82. https:// doi.org/10.3109/17482960903262083.

194. Lindeman NI, Cagle PT, Aisner DL, Arcila ME, Beasley MB, Bernicker $\mathrm{EH}$, et al. Updated molecular testing guideline for the selection of lung cancer patients for treatment with targeted tyrosine kinase inhibitors: guideline from the College of American Pathologists, the International Association for the Study of Lung Cancer, and the Association for Molecular Pathology. J Mol Diagn. 2018;20(2):129-59. https://doi.org/10.1016/j.jmold x.2017.11.004.

195. Jain D, Roy-Chowdhuri S. Molecular pathology of lung cancer cytology specimens: a concise review. Arch Pathol Lab Med. 2018;142(9):1127-33. https://doi.org/10.5858/ arpa.2017-0444-RA.

196. Roy-Chowdhuri S, Pisapia P, Salto-Tellez M, Savic S, Nacchio $\mathrm{M}$, de Biase D, et al. Invited review-next-generation sequencing: a modern tool in cytopathology. Virch Arch. 2019;475(1):3-11. https://doi.org/10.1007/s00428-019-02559-z.

197. Xing L, Pan Y, Shi Y, Shu Y, Feng J, Li W, et al. Biomarkers of osimertinib response in patients with refractory, EGFR-T790M-positive non-small cell lung cancer and central nervous system metastases: the APOLLO study. Clin Cancer Res. 2020;26(23):6168-75. https://doi.org/10.1158/1078-0432. CCR-20-2081.

198. Zheng MM, Li YS, Tu HY, Jiang BY, Yang JJ, Zhou Q, et al. Genotyping of cerebrospinal fluid associated with osimertinib response and resistance for leptomeningeal metastases in EGFR-mutated NSCLC. J Thorac Oncol. 2020. https://doi. org/10.1016/j.jtho.2020.10.008.

199. Verhaak RGW, Hoadley KA, Purdom E, Wang V, Qi Y, Wilkerson MD, et al. Integrated genomic analysis identifies clinically relevant subtypes of glioblastoma characterized by abnormalities in PDGFRA, IDH1, EGFR, and NF1. Cancer Cell. 2010;17(1):98-110. https://doi.org/10.1016/j.ccr.2009.12.020.

200. Cejalvo JM, Martínez de Dueñas E, Galván P, García-Recio S, Burgués Gasión $\mathrm{O}$, Paré L, et al. Intrinsic subtypes and gene expression profiles in primary and metastatic breast cancer. Cancer Res. 2017;77(9):2213-21. https://doi.org/10.1158/00085472.CAN-16-2717.

201. Lanz TV, Probstel AK, Mildenberger I, Platten M, Schirmer L. Single-cell high-throughput technologies in cerebrospinal fluid research and diagnostics. Front Immunol. 2019;10:1302. https:// doi.org/10.3389/fimmu.2019.01302.

202. Diaz-Ortiz ME, Chen-Plotkin AS. Omics in neurodegenerative disease: hope or hype? Trends Genet. 2020;36(3):152-9. https ://doi.org/10.1016/j.tig.2019.12.002.

203. Pan C, Diplas BH, Chen X, Wu Y, Xiao X, Jiang L, et al. Molecular profiling of tumors of the brainstem by sequencing of CSF-derived circulating tumor DNA. Acta Neuropathol. 2019;137(2):297-306. https://doi.org/10.1007/s0040 1-018-1936-6.

204. Grommes C, Tang SS, Wolfe J, Kaley TJ, Daras M, Pentsova EI, et al. Phase $1 \mathrm{~b}$ trial of an ibrutinib-based combination therapy in recurrent/refractory CNS lymphoma. Blood. 2019;133(5):43645. https://doi.org/10.1182/blood-2018-09-875732.

205. Zhao Y, He JY, Cui JZ, Meng ZQ, Zou YL, Guo XS, et al. Detection of genes mutations in cerebrospinal fluid circulating tumor DNA from neoplastic meningitis patients using next generation sequencing. BMC Cancer. 2020;20(1):690. https://doi. org/10.1186/s12885-020-07172-x.

206. Li YS, Zheng MM, Jiang BY, Tu HY, Yang JJ, Zhang XC, et al. Association of cerebrospinal fluid tumor DNA genotyping with survival among patients with lung adenocarcinoma and central nervous system metastases. JAMA Netw Open. 2020;3(8):e209077. https://doi.org/10.1001/jamanetworkopen 2020.9077.

207. Miao Q, Zheng X, Zhang L, Jiang K, Wu B, Lin G. Multiple combination therapy based on intrathecal pemetrexed in nonsmall cell lung cancer patients with refractory leptomeningeal metastasis. Ann Palliat Med. 2020;9(6):4233-45. https://doi. org/10.21037/apm-20-2086.

208. Ma C, Huang C, Tang D, Ye X, Li Z, Liu R, et al. Afatinib for advanced non-small cell lung cancer in a case with an uncommon epidermal growth factor receptor mutation (G719A) identified in the cerebrospinal fluid. Front Oncol. 2019;9:628. https://doi. org/10.3389/fonc.2019.00628.

209. Guo X, Cui J, Zhao Y, Han W, Zou Y, Gao R, et al. The therapeutic value of cerebrospinal fluid ctDNA detection by nextgeneration sequencing for meningeal carcinomatosis: a case report. BMC Neurol. 2019;19(1):38. https://doi.org/10.1186/ s12883-019-1266-x. 